\title{
Sensitivity of asymmetric Oxygen Minimum Zones to remineralization rate and mixing intensity in the tropical Pacific using a basin-scale model (OGCM-DMEC V1.2)
}

\author{
Kai Wang ${ }^{1}$, Xiujun Wang ${ }^{1,2 *}$, Raghu Murtugudde ${ }^{2}$, Dongxiao Zhang ${ }^{3}$, Rong-Hua Zhang ${ }^{4}$
}

$5 \quad{ }^{1}$ College of Global Change and Earth System Science, Beijing Normal University, Beijing 100875, China ${ }^{2}$ Earth System Science Interdisciplinary Center, University of Maryland, College Park, Maryland 20740, USA ${ }^{3}$ JISAO, University of Washington and NOAA, Pacific Marine Environmental Laboratory, Seattle, Washington 98115, USA ${ }^{4}$ Institute of Oceanology, Chinese Academy of Sciences, Qingdao, Shandong 266071, China

Correspondence to: Xiujun Wang (xwang@bnu.edu.cn)

10 Abstract. The tropical Pacific Ocean holds the world's two largest Oxygen Minimum Zones (OMZs), showing a prominent hemispheric asymmetry, with a much stronger and broader OMZ north of the equator. However, many models have difficulties in reproducing the observed asymmetric OMZs in the tropical Pacific. Here, we apply a fully coupled basin-scale model (OGCM-DMEC V1.2) to evaluate the impacts of remineralization rate and the intensity of vertical mixing on the dynamics of OMZs in the tropical Pacific. We first utilize observational data of dissolved oxygen (DO), dissolved organic

15 nitrogen (DON) and oxygen consumption to calibrate and validate the basin-scale model. Our model experiments demonstrate that enhanced vertical mixing combined with reduced remineralization rate can significantly improve our model capability of reproducing the asymmetric OMZs. Our study shows that DO is more sensitive to biological processes over 200-400 m but to physical processes over 400-1000 m. Enhanced vertical mixing not only causes an increase in DO supply at mid-depth, but also results in lower rates of biological consumption in the OMZs, which is associated with redistribution of DON. Our analyses demonstrate that weaker physical supply in the ETNP is the dominant process responsible for the asymmetry of the lower OMZs whereas greater biological consumption to the north plays a larger role in regulating the upper OMZs. This study highlights the complex roles of physical supply and biological consumption in shaping the asymmetric OMZs in the tropical Pacific.

\section{Introduction}

25 Photosynthesis and respiration are important processes in all ecosystems on the Earth, with carbon and oxygen being the two main elements. The carbon cycle has garnered much attentions, which made significant progresses in both the observations and modelling of biological processes (e.g., uptake of $\mathrm{CO}_{2}$ and respiration), and physical/chemical processes (e.g., carbon fluxes between the atmosphere, land and ocean). However, the oxygen cycle has received much less attention despite its large role in the earth system (Breitburg et al., 2018; Oschlies et al., 2018). 
https://doi.org/10.5194/gmd-2020-431

Preprint. Discussion started: 4 March 2021

(c) Author(s) 2021. CC BY 4.0 License.

Dissolved oxygen (DO) is a sensitive indicator of physical and biogeochemical processes in the ocean thus a key parameter for understanding the ocean's role in the climate system (Stramma et al., 2010). In addition to photosynthesis and respiration, the distribution of DO in the world's oceans is also regulated by air-sea gas exchange, ocean circulation and ventilation (Bopp et al., 2002; Bettencourt et al., 2015; Levin, 2018). Unlike most dissolved nutrients that display an increase in concentration with depth, DO concentration is generally low at mid-depth of the ocean. The most remarkable feature in the oceanic oxygen dynamics is the so-called Oxygen Minimum Zone (OMZ) that is often present below $200 \mathrm{~m}$ in the open oceans (Karstensen et al., 2008; Stramma et al., 2008).

The world's two largest OMZs are observed in the Eastern Tropical North Pacific (ETNP) and South Pacific (ETSP),

40 showing a peculiar asymmetric structure across the equator, i.e., a much larger volume of suboxic water $\left(<20 \mathrm{mmol} \mathrm{m}^{-3}\right)$ to the north than to the south (Paulmier and Ruiz-Pino, 2009; Bettencourt et al., 2015). It is known that OMZs are caused by the biological consumption associated with remineralization of organic matter (OM), and weak physical supply of DO due to sluggish subsurface ocean circulation and ventilation (Czeschel et al., 2011; Brandt et al., 2015; Kalvelage et al., 2015). Although there have been a number of observation based analyses addressing the dynamics of OMZs in the tropical Pacific

45 during the past decade (Stramma et al., 2010; Czeschel et al., 2012; Schmidtko et al., 2017; Garçon et al., 2019), our understanding is uncompleted in terms of the underlying mechanisms that regulate DO dynamics at mid-depth due to the limitation of available data (Stramma et al., 2012; Oschlies et al., 2018).

Large-scale physical-biogeochemical models have become a useful tool to investigate the potential sensitivity of OMZs to 50 climate change (Duteil and Oschlies, 2011; Williams et al., 2014; Ward et al., 2018). However, many models still have some difficulties in reproducing observed asymmetric OMZs in the tropical Pacific (Cabre et al., 2015; Shigemitsu et al., 2017), which may be due to "unresolved ocean transport processes, unaccounted for variations in respiratory oxygen demand, or missing biogeochemical feedbacks" (Oschlies et al., 2018). A common problem is that the two asymmetric OMZs merge into one in most models that often overestimate the volume of OMZs in the tropical Pacific, which may be related to weaker physical supply and/or higher rates of biological consumption (Cabre et al., 2015; Shigemitsu et al., 2017). Recent studies have also indicated that a realistic representation of circulation and ventilation processes with a high-resolution ocean model is critical to predict the asymmetric OMZs in the tropical Pacific (Berthet et al., 2019; Busecke et al., 2019). Apparently, it's necessary to carry out model-data integrative studies to improve model capacity of simulating the dynamics of the tropical OMZs, and to better understand the relative roles of physical and biological processes.

A basin-scale ocean general circulation model coupled with a dynamic marine ecosystem-carbon model (OGCM-DMEC) was developed for the tropical Pacific (Wang et al., 2008; Wang et al., 2009b; Wang et al., 2015), which showed capability of reproducing observed spatial and temporal variations of physical, nutrient and carbon fields in the upper ocean. In this study, we conduct model sensitivity experiments and evaluation on responses of mid-depth DO to parameterizations of two 
65 relevant processes (i.e., remineralization and vertical mixing). We first carry out model calibration and validation using observational data of DO and consumption rate to improve the simulation of OMZs in the tropical Pacific. Then, we use the improved model to evaluate how biological consumption and physical supply regulate the dynamics of mid-depth DO. The objective of this study is to advance our model capacity to simulate the oceanic oxygen cycle, and to identify the mechanisms driving the asymmetric OMZs in the tropical Pacific.

\section{2. Model description}

\subsection{Ocean physical model}

The basin-scale OGCM, a reduced-gravity, primitive-equation, sigma-coordinate model, is coupled to an advective atmospheric model (Murtugudde et al., 1996). There are 20 layers with variable thicknesses in the OGCM. The mixed layer (the upper-most layer) depth is determined by the Chen mixing scheme (Chen et al., 1994), which varies from $10 \mathrm{~m}$ to $50 \mathrm{~m}$ on the equator. The remaining layers in the euphotic zone are approximately $10 \mathrm{~m}$ in thickness. The model domain is between $30^{\circ} \mathrm{S}$ and $30^{\circ} \mathrm{N}$, and zonal resolution is $1^{\circ}$. Meridional resolution varies between $0.3^{\circ}$ and $0.6^{\circ}$ over $15^{\circ} \mathrm{S}-15^{\circ} \mathrm{N}\left(1 / 3^{\circ}\right.$ over $10^{\circ} \mathrm{S}-10^{\circ} \mathrm{N}$ ), and increases to $2^{\circ}$ in the southern and northern "sponge layers" (the $25^{\circ}-30^{\circ}$ bands) where temperature, salinity, and nitrate are gradually relaxed back towards the observed climatological seasonal means from the World Ocean Atlas, 2013 (WOA2013: http://www.nodc.noaa.gov/OC5/woa13/pubwoa13.html).

The model is forced by atmospheric conditions: climatological monthly means of solar radiation and cloudiness, and interannual 6-day means of precipitation and surface wind stress. Precipitation is from ftp://ftp.cdc.noaa.gov/Datasets/gpcp. Wind stresses are from the National Centers for Environmental Prediction (NCEP) reanalysis (Kalnay et al., 1996). Air temperature and humidity above the ocean surface are computed by the atmospheric mixed layer model. Initial conditions were obtained from outputs of an interannual hindcast simulation over 1948-1978, which itself is initialized from a climatological run with a 30-year spin up. The initial conditions for the climatological spin up are specified from the WOA2013. We carry out an interannual simulation for the period of 1978-2018, and analyse model output for the period of 1981-2000.

\subsection{Ocean biogeochemical model}

90 The DMEC model is the main part of the biogeochemical model that is embedded in the basin-scale OGCM. The DMEC model consists of eleven components: small (S) and large (L) sizes of phytoplankton $\left(P_{S}\right.$ and $\left.P_{L}\right)$, zooplankton $\left(Z_{S}\right.$ and $\left.Z_{L}\right)$ and detritus $\left(D_{S}\right.$ and $\left.D_{L}\right)$, dissolved organic nitrogen (DON), ammonium, nitrate, dissolved iron, and DO (Figure 1). All biological components use nitrogen as their unit, and are computed in a manner similar to physical variables.

In this model, net community production (NCP) is computed as: 
where 6.625 is the $\mathrm{C}: \mathrm{N}$ ratio, $\mu$ the rate of phytoplankton growth, $r$ the rate of zooplankton respiration, $c$ the rates of detritus decomposition and DON remineralization. The equations for biogeochemical processes and model parameters are described in Appendix A and B. There have been changes in some parameters comparing with those in Wang et al. (2008), which were based on our model calibration and validation for chlorophyll (Wang et al., 2009a), nitrogen cycle (Wang et al., 2009b) and carbon cycle (Wang et al., 2015).

\subsection{Computation of oxygen sources and sinks}

The time evolution of DO is regulated by physical, biological and chemical processes:

$\frac{\partial O_{2}}{\partial t}=-u \frac{\partial O_{2}}{\partial x}-v \frac{\partial O_{2}}{\partial y}-w \frac{\partial O_{2}}{\partial z}+O_{\text {mix }}-O_{\text {bio }}+O_{g a s}$

where $u, v$, and $w$ are zonal, meridional, and vertical velocity, respectively. $O_{m i x}$ is the vertical mixing term that is calculated by three subroutines. Briefly, the first one computes convection to remove instabilities in the water column, and the second one determines the mixed layer depth. The third one computes partial vertical mixing $\left(\mathrm{K}_{\mathrm{z}}\right)$ between two adjacent layers to relieve gradient Richardson $\left(\mathrm{R}_{\mathrm{i}}\right)$ number instability, which is calculated as follows:

$K_{z}=\left(1-\left(\frac{R i}{0.7}\right)^{\lambda}\right)(R i<0.7)$

$K_{z}=0(R i \geq 0.7)$

110 where the mixing parameter $\lambda$ is set to 1 .

The biological source/sink term $O_{b i o}$ is computed as follows:

$$
O_{\text {bio }}=1.3 \mathrm{NCP}
$$

where 1.3 is the O:C Redfield ratio. Below the euphotic zone, DO concentration is determined by physical supply and biological consumption that results from detritus decomposition and DON remineralization, in which DON remineralization is dominant because DON poor is several times greater than detritus (Wang et al., 2008).

The flux of $\mathrm{O}_{2}$ from the atmosphere to the surface ocean is computed as:

$O_{\text {gas }}=\left(O_{\text {sat }}-O\right) K_{0}$

120 where $O_{\text {sat }}$ is the $\mathrm{O}_{2}$ saturation, a function of temperature and salinity (Weiss, 1970), and $K_{0}$ the gas transfer velocity that is a function of wind speed $\left(u_{s}\right)$ and SST according to Wanninkhof (1992):

$K_{0}=0.31 u_{s}^{2} \sqrt{\frac{S c}{S c 20}}$

where $S c$ and $S c_{20}$ are the Schmidt number at SST and $20^{\circ} \mathrm{C}$, respectively:

$S_{c}=1953-128 T+3.99 T^{2}-0.05 T^{3}$ 
https://doi.org/10.5194/gmd-2020-431

Preprint. Discussion started: 4 March 2021

(c) Author(s) 2021. CC BY 4.0 License.

(c) (i)

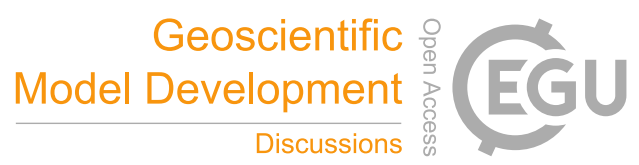

\section{3. Model experiments and validation}

\subsection{Evaluation of DO distribution from the reference run}

We first evaluate simulated DO for the tropical Pacific Ocean using the outputs from OGCM-DMEC V1.2 (hereafter reference run). We focus on model-data comparisons over 200-400 m, 400-700 m and 700-1000 m that broadly represent the upper OMZ, lower OMZ and beneath OMZ, respectively. The WOA2013 data shows a much larger area of suboxic waters

$130\left(<20 \mathrm{mmol} \mathrm{m}^{-3}\right)$ in the ETNP than in the ETSP over 200-400 $\mathrm{m}$ and 400-700 $\mathrm{m}$ (Figure 2a and 2c), but no suboxic water over 700-1000 m (Figure 2e). Although the reference run produces two OMZs off the equator over 200-400 m (Figure 2b), the sizes of suboxic water are much larger in the reference run than those in the WOA2013 data. The reference run significantly over-estimate the size of suboxic water and underestimates DO concentration over 400-700 m (Figure 2d). The difference between WOA2013 and the reference run is small over 700-1000 m, except in the eastern tropical Pacific (Figure 2f). The relative roles of the physics vs. the biogeochemistry in determining the bias are diagnosed further below.

\subsection{Sensitivity experiments}

Given that the mid-depth DO concentration is influenced by physical supply and biological consumption, and remineralization of DON is the dominant process for oxygen consumption, the underestimated DO at mid-depth would be a

140 result of overestimation of consumption associated with DON remineralization and/or underestimation of supply. Indeed, the reference run over-estimates biological consumption over 100-400 m (Figure 3). Thus, we apply a reduced DON remineralization constant (50\% of the reference run), which leads to a remarkable improvement in simulated DON and consumption. The reference run applies a zero value for background diffusion. However, a previous modelling study has demonstrated that vertical background diffusion is an important process for DO supply at mid-depth (Duteil and Oschlies,

145 2011). Accordingly, we conduct a few more simulations (Table 1) to investigate how reducing remineralization rate and applying different values for vertical background diffusion $\left(\mathrm{Kb}=0.1,0.3\right.$, or $\left.0.5 \mathrm{~cm}^{2} \mathrm{~s}^{-1}\right)$ affect simulated DO distribution and asymmetric OMZs in the tropical Pacific. Changing the intensity of vertical diffusion has relatively small influence on vertical distributions of DON and DO consumption in the OMZ (Figure 3).

150 We then compare simulated DO and WOA2013 climatology data. Figure 4a illustrates a larger volume of suboxic water located north of $\sim 5^{\circ} \mathrm{N}$ and a smaller volume of suboxic water over $12^{\circ} \mathrm{S}-4^{\circ} \mathrm{S}$, which are separated by relatively higher DO $\left(>30 \mathrm{mmol} \mathrm{m}^{-3}\right.$ ) along the equator. Both $\mathrm{Cd} 0.5$ run (Figure $4 \mathrm{c}$ ) and the reference run (Figure $4 \mathrm{~b}$ ) produce much larger volumes of suboxic water that are extend to the equatorial region, and even merge into one. Clearly, there is an improvement in simulated DO with vertical background diffusion (Figure 4d, 4e and 4f). Overall, Cd0.5Kb0.5 is able to capture the

155 observed spatial distribution of DO, especially the asymmetric feature (i.e., a larger volume of suboxic water to the north but a smaller size of suboxic water to the south), and relatively higher DO $\left(\sim 30-40 \mathrm{mmol} \mathrm{m}^{-3}\right)$ over $2^{\circ} \mathrm{S}-2^{\circ} \mathrm{N}$. 


\subsection{Model validation}

To further evaluate the performance of experiments, three statistical measures are applied over 200-400 m, 400-700 m and $700-1000 \mathrm{~m}$ in the ETNP $\left(165^{\circ} \mathrm{W}-90^{\circ} \mathrm{W}, 5^{\circ}-20^{\circ} \mathrm{N}\right)$ and ETSP $\left(110^{\circ} \mathrm{W}-80^{\circ} \mathrm{W}, 10^{\circ} \mathrm{S}-3^{\circ} \mathrm{S}\right)$. As shown in Table 2 , compared to the reference run, bias, MAE and RMSE all decrease in the new experiments, with the smallest values from Cd0.5Kb0.5 run except over 700-1000 $\mathrm{m}$ in the ETNP. For example, both MAE and RMSE are lowest from Cd0.5Kb0.5 run over 200-700 m in the ETNP (6.95-16.44 $\mathrm{mmol} \mathrm{m}^{-3}$ ) and over 200-1000 $\mathrm{m}$ in ETSP (3.12-7.59 mmol $\mathrm{m}^{-3}$ ). Many current models show much large RMSE ( 20-80 $\mathrm{mmol} \mathrm{m}^{-3}$ ) with respect to observed DO from mixed layer to $1000 \mathrm{~m}$ (Cabre et al., 2015; Bao and Li,

165 2016). Figure 5 also illustrates that $\mathrm{Cd} 0.5 \mathrm{~Kb} 0.5$ run produces the best outputs, with the largest correlation coefficients (0.77$0.94)$ and also the smallest distance to 1 in normalized standard deviation (0.54-1.81 in ETNP and 0.33-1.63 in ETSP).

We also compare the sizes of suboxic water and hypoxic water between model and WOA2013 (Table 3). Based on WOA2013, we estimate that the sizes of suboxic water and hypoxic water are $5.97 \times 10^{15} \mathrm{~m}^{3}$ and $19.98 \times 10^{15} \mathrm{~m}^{3}$ in the north,

170 and $1.43 \times 10^{15} \mathrm{~m}^{3}$ and $7.12 \times 10^{15} \mathrm{~m}^{3}$ in the south, respectively. While the Cd0.5 run (with a reduced remineralization rate) results in an improvement in simulated OMZ volume, significant improvements are obtained with the combination of reduced remineralization and enhanced vertical mixing (i.e., with background diffusion). Overall, the best performance for reproducing $\mathrm{OMZ}$ volume is $\mathrm{Cd} 0.5 \mathrm{~Kb} 0.5$ simulation that predicts similar volumes for the suboxic water $\left(6.61 \times 10^{15} \mathrm{~m}^{3}\right.$ to the north and $1.56 \times 10^{15} \mathrm{~m}^{3}$ to the south) and the hypoxic water $\left(19.62 \times 10^{15} \mathrm{~m}^{3}\right.$ and $\left.7.13 \times 10^{15} \mathrm{~m}^{3}\right)$. We then use cruise data to

175 further validate modelled DO from the best run $(\mathrm{Cd} 0.5 \mathrm{~Kb} 0.5)$. Figure 6 shows that the model can generally reproduce the vertical-zonal distribution of DO along $10^{\circ} \mathrm{N}$ and $17^{\circ} \mathrm{S}$, spanning from 1989 to 2009 , particularly in the eastern tropical Pacific.

\section{Model evaluation and discussions}

In this section, we further compare the improved model simulations $(\mathrm{Cd} 0.5$ and $\mathrm{Cd} 0.5 \mathrm{~Kb} 0.5)$ with reference run to diagnose

180 the relative contributions of biological consumption and physical supply to the asymmetric OMZs in the tropical Pacific, aiming to identify the underlying mechanisms regulating the dynamics of mid-depth DO.

\subsection{Changes of mid-depth DO due to reduced remineralization and enhanced mixing}

We first compare the changes of DO concentration between the three model simulation over 200-400 m, 400-700 m, and

185 700-1000 m (Figure 7). Clearly, reduced remineralization rate largely increase mid-depth DO in all three layers, with a greater increase $\left(\sim 0-22 \mathrm{mmol} \mathrm{m}^{-3}\right)$ over $200-400 \mathrm{~m}$ (Figure $\left.7 \mathrm{a}\right)$, a modest increase $\left(\sim 0-6 \mathrm{mmol} \mathrm{m}^{-3}\right)$ over $400-700 \mathrm{~m}($ Figure $7 \mathrm{~d})$, and a small increase $\left(0-3 \mathrm{mmol} \mathrm{m}^{-3}\right)$ over 700-1000 $\mathrm{m}$ (Figure $\left.7 \mathrm{~h}\right)$. Enhanced vertical mixing results in a small increase 
https://doi.org/10.5194/gmd-2020-431

Preprint. Discussion started: 4 March 2021

(c) Author(s) 2021. CC BY 4.0 License.

in DO (<10 mmol m $\mathrm{m}^{-3}$ ) over 200-400 $\mathrm{m}$ (Figure 7b) but a large increase (5-12 $\mathrm{mmol} \mathrm{m} \mathrm{m}^{-3}$ ) over 400-700 $\mathrm{m}$ and 700-1000 $\mathrm{m}$ (Figure 7e and 7i). A number of modelling studies have demonstrated that parameterization of vertical mixing has significant impacts on the mean state of DO distributions at mid-depth (Duteil and Oschlies, 2011; Gnanadesikan et al., 2013).

We also assess the response of mid-depth DO to the combination of reduced remineralization rate and enhanced vertical mixing (Cd0.5Kb0.5 minus reference run). Overall, the increase of DO is greater over $200-400 \mathrm{~m}\left(\sim 10-24 \mathrm{mmol} \mathrm{m}^{-3}\right)$ than over 400-700 $\mathrm{m}\left(\sim 8-18 \mathrm{mmol} \mathrm{m}^{-3}\right)$ and 700-1000 $\mathrm{m}\left(\sim 6-12 \mathrm{mmol} \mathrm{m}^{-3}\right)$ (Figure 7c, 7f \& 7j). The spatial pattern and magnitude of increased DO resulted from the combined changes of remineralization rate and vertical mixing have a large similarity to those caused by reduced remineralization rate for the 200-400 m layer (Figure 7a), but are similar to those due to enhanced mixing below $400 \mathrm{~m}$ (Figure $7 \mathrm{~d} \& 7 \mathrm{~h}$ ). Our analyses indicate that DO dynamics is regulated by biological processes above $400 \mathrm{~m}$, but by physical processes over 400-1000 $\mathrm{m}$. The larger biological influence on the upper OMZ is attributable to the greater rate of DO consumption (Karstensen et al., 2008) whereas the greater physical impact on the lower $\mathrm{OMZ}$ reflects the relatively larger role of supply than consumption.

\subsection{Responses of consumption and supply to reduced remineralization and enhanced mixing}

We then evaluate the changes of biological consumption and physical supply of DO due to reduced remineralization and/or enhanced mixing. Reducing remineralization rate by $50 \%$ (Cd0.5 minus reference) leads to large decrease ( 1.5-2.0 mmol m-

$\left.{ }^{3} \mathrm{yr}^{-1}\right)$ over 200-400 m, modest decrease ( 0.2-0.5 $\left.\mathrm{mmol} \mathrm{m}^{-3} \mathrm{yr}^{-1}\right)$ over 400-700 m and small decrease ( 0.1-0.2 $\left.\mathrm{mmol} \mathrm{m}^{-3} \mathrm{yr}^{-1}\right)$ over 700-1000 m (Figure 8a, 8d and 8h). On the other hand, enhanced vertical mixing causes much greater increase of supply over 400-1000 m than over 200-400 m. Numerous studies have indicated that physical mixing is the only source of DO for the tropical OMZs (Czeschel et al., 2012; Brandt et al., 2015; Talley et al., 2016). For example, turbulent background diffusion accounts for $89 \%$ of the net DO supply for the core OMZ layer of south tropical Pacific (Llanillo et al., 2018). Figure 8e and $8 \mathrm{i}$ illustrate that physical supply is increased by $\sim 0.2-0.6 \mathrm{mmol} \mathrm{m}^{-3} \mathrm{yr}^{-1}$ in most of the mid-waters, with the largest increase in the southern part of central equatorial Pacific over 400-700 m. However, there is somehow a small decrease of physical supply in the ETNP over 200-400 m (by $\sim 0.03 \mathrm{mmol} \mathrm{m}^{-3} \mathrm{yr}^{-1}$, Figure 8 b) and 400-700 $\mathrm{m}(<0.02 \mathrm{mmol}$ $\mathrm{m}^{-3} \mathrm{yr}^{-1}$, Figure 8e), implying that increased DO under enhanced vertical mixing may be attributable to changes in biological consumption.

We further compare biological consumption between $\mathrm{Cd} 0.5 \mathrm{~Kb} 0.5$ and the $\mathrm{Cd} 0.5$. Interestingly, enhanced vertical mixing results in a decrease in consumption, with the largest decreases ( $\left.~ 0.03-0.07 \mathrm{mmol} \mathrm{m}^{-3} \mathrm{yr}^{-1}\right)$ over 400-700 $\mathrm{m}$ (Figure 8f), the smallest decrease ( 0.01-0.04 mmol m $\mathrm{mr}^{-1}$ ) over 200-400 $\mathrm{m}$ (Figure $8 \mathrm{c}$ ) and modest decrease of $\sim 0.02-0.04 \mathrm{mmol} \mathrm{m}^{-3} \mathrm{yr}^{-1}$ over 700-1000 m (Figure 8j). For the northern OMZ, biological consumption decreases by $\sim 0.03-0.07 \mathrm{mmol} \mathrm{m}^{-3} \mathrm{yr}^{-1}$ over $220200-700 \mathrm{~m}$ (Figure $8 \mathrm{c}$ and $8 \mathrm{f}$ ), which is larger than the decreased rate $\left(\sim 0.01-0.03 \mathrm{mmol} \mathrm{m}^{-3} \mathrm{yr}^{-1}\right.$ ) of physical supply (Figure $8 \mathrm{~b}$ and $8 \mathrm{e}$ ). 
Remineralization rate of DOM in the ocean is determined by the size of DOM pool and temperature (Wang et al., 2008; Brewer and Peltzer, 2016). Given that there is little difference $\left(<10^{-5}{ }^{\circ} \mathrm{C}\right)$ in seawater temperature between different model experiments, the reduced consumption rates due to DOM remineralization would be a result of a smaller amount of DOM. Here, we evaluate the zonal and meridional distributions of DON together with remineralization rate. As shown in Figure 9a$9 \mathrm{~d}$, modelled consumption decreases from $\sim 8 \mathrm{mmol} \mathrm{m}^{-3} \mathrm{yr}^{-1}$ in the euphotic zone to $\sim 1-2 \mathrm{mmol} \mathrm{m}^{-3} \mathrm{yr}^{-1}$ below $400 \mathrm{~m}$, and modelled DON decreases from 5-8 $\mathrm{mmol} \mathrm{N} \mathrm{m}^{-3}$ near the surface to 1-4 $\mathrm{mmol} \mathrm{N} \mathrm{m}^{-3}$ over 400-1000 $\mathrm{m}$. Limited field studies reported that surface DON concentration was $\sim 5-7 \mathrm{mmol} \mathrm{N} \mathrm{m}^{-3}$ in the ETSP (Loginova et al., 2019), and consumption rate ranged from $8.3 \mathrm{mmol} \mathrm{m}^{-3} \mathrm{yr}^{-1}$ at $\sim 200 \mathrm{~m}$ to $<3.1 \mathrm{mmol} \mathrm{m}^{-3} \mathrm{yr}^{-1}$ below $500 \mathrm{~m}$ in the subtropical North Pacific (Sonnerup et al., 2013), which are comparable to our model results. Our model simulations indicate that enhanced vertical mixing leads to a redistribution of DON below $200 \mathrm{~m}$, with a decrease in DON concentration $\left(0.06-0.12 \mathrm{mmol} \mathrm{N} \mathrm{m}{ }^{-3}\right)$ over $600-900 \mathrm{~m}$, but an increase $\left(<0.04 \mathrm{mmol} \mathrm{N} \mathrm{m}^{-3}\right.$ ) below $1000 \mathrm{~m}$ in the eastern tropical Pacific (Figure 9h, 9i and 9j).

4.3 Impacts of biological consumption and physical supply on asymmetry of OMZs

Previous studies have demonstrated meridional asymmetric features in many physical and biological fields in the tropical Pacific, e.g., temperature and salinity (Fiedler and Talley, 2006), circulation and ventilation (Kessler, 2006; Kuntz and Schrag, 2018), nitrogen and carbon cycles (Libby and Wheeler, 1997; Wang et al., 2009b), which may be largely associated with the asymmetries in water mass exchange between the equatorial and off-equator Pacific Ocean (Kug et al., 2003). Accordingly, one may assume that the hemisphere asymmetry of OMZs could be related to the differences in physical supply and biological consumption between the ETNP and ETSP.

There is evidence that the size of tropical OMZ is largely influenced by biological processes, such as organic matter export and oxygen consumption (Keller et al., 2016; Cavan et al., 2017). Figure 10a illustrates that DO is increased in both ETNP and ETSP over 200-1000 m when remineralization rate decreases by $50 \%$. The increase of DO is generally greater in the ETSP than in ETNP, except in the core OMZ ( 300-500 m). Earlier field studies have revealed that DON concentration is much higher to the north than to the south in the central-eastern tropical Pacific (Libby and Wheeler, 1997; Raimbault et al., 1999). Later studies showed that rates of DOM remineralization and/or oxygen consumption are also greater at mid-depth in the ETNP than in the ETSP (Feely et al., 2004; Tiano et al., 2014; Kalvelage et al., 2015), indicating that biological processes play a big role in determining the asymmetry of upper OMZs.

Recent studies also emphasized the role of changes in physical processes for the observed asymmetric OMZs in the tropical oceans. For instance, there is evidence that larger-scale mass transport related to circulation and ventilation in the southern hemisphere is more efficient than in the northern hemisphere (Kuntz and Schrag, 2018), and the transit time from the surface to the OMZ is much longer in the ETNP than in the ETSP (Sonnerup et al., 2013; Fu et al., 2018). Clearly, our model 
experiment shows that enhanced vertical mixing leads to a significant increase in DO concentration below $200 \mathrm{~m}$ (Figure 10b). The increase of DO is similar below $1000 \mathrm{~m}$ in the ETNP and ETSP, but differs largely between the two regions, with much greater values over 200-1000 $\mathrm{m}$ in the ETSP. Our analysis indicates that enhanced vertical mixing increases the physical supply of DO over most of the water column, except over 300-500 $\mathrm{m}$ in the ETNP showing a small decrease (Figure 10c). The increase of supply is greater over $200-1000 \mathrm{~m}$ in the ETSP than in the ETNP, and significant increases $(>0.2 \mathrm{mmol}$ $\left.\mathrm{m}^{-3} \mathrm{yr}^{-1}\right)$ are below $600 \mathrm{~m}(500 \mathrm{~m})$ in the ETNP (ETSP). These analyses indicate that physical transport may be largely responsible for the asymmetry of lower OMZs.

\section{Conclusion}

265 This paper describes an evaluation and validation of a fully coupled basin-scale model (OGCM-DMEC V1.2), focusing on the sensitivity of the asymmetric OMZs in the tropical Pacific to different parameterizations of remineralization and vertical mixing. Our results show that the improved model with enhanced vertical mixing combined with reduced remineralization successfully reproduces the observed asymmetric OMZs in the tropical Pacific.

270 Our results demonstrate that reduced remineralization rate leads to remarkable decrease of biological consumption over 200$400 \mathrm{~m}$, which largely affects the distribution of DO in the upper OMZ. On the other hand, enhanced vertical mixing causes a significant increase in physical supply of DO over 400-1000 m. Apart from the direct impact on physical supply, enhanced vertical mixing also results in the redistribution of DOM in the water column, i.e., an increase over 200-1000 $\mathrm{m}$ and a decrease below $1000 \mathrm{~m}$, leading to lower consumption in the OMZs.

Further analyses indicate that the asymmetric OMZs in the tropical Pacific are attributable to the asymmetry in both physical supply and biological consumption. The larger volume of northern OMZ is a result of greater biological consumption and weaker physical supply to the north, in which physical supply plays a dominant role in the lower OMZs but biological consumption also has impacts on the asymmetric DO for the upper OMZs. Future studies utilizing advanced models are needed to better understand the impacts of physical and biological interactions on the variability and drivers of the tropical OMZs. 
https://doi.org/10.5194/gmd-2020-431

Preprint. Discussion started: 4 March 2021

(C) Author(s) 2021. CC BY 4.0 License.

(c) (i)

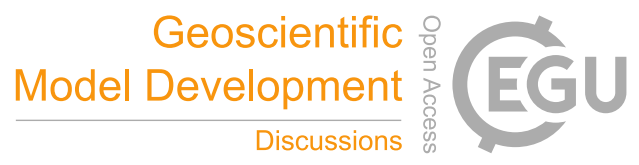

Code and data availability. The exact version of the software code used to produce the results presented in this paper is

285 archived on Zenodo (http://doi.org/10.5281/zenodo.4384131, Wang et al., 2020). Other code and data are available upon request from the authors. Request for materials should be addressed to X.J.W. (xwang@bnu.edu.cn).

Author contributions. X.J.W. and K.W. designed the study, performed the simulations and prepared the manuscript. R.M., D.X.Z. and R.H.Z. contributed to analysis, interpretation of results and writing.

290

Competing interests. The authors declare that they have no conflict of interest.

Acknowledgements. This work was supported by the Chinese Academy of Sciences' Strategic Priority Project (XDA1101010504). The authors wish to acknowledge the use of the Ferret (http://ferret.pmel.noaa.gov/Ferret/). 
https://doi.org/10.5194/gmd-2020-431

Preprint. Discussion started: 4 March 2021

(C) Author(s) 2021. CC BY 4.0 License.

\section{References}

Bao, Y., Li, Y., 2016. Simulations of dissolved oxygen concentration in CMIP5 Earth system models. Acta Oceanologica Sinica 35, 28-37.

300 Berthet, S., Séférian, R., Bricaud, C., Chevallier, M., Voldoire, A., Ethé, C., 2019. Evaluation of an Online Grid Coarsening Algorithm in a Global Eddy - Admitting Ocean Biogeochemical Model. Journal of Advances in Modeling Earth Systems 11, 1759-1783.

Bettencourt, J.H., Lopez, C., Hernandez-Garcia, E., Montes, I., Sudre, J., Dewitte, B., Paulmier, A., Garcon, V., 2015. Boundaries of the Peruvian oxygen minimum zone shaped by coherent mesoscale dynamics. Nature Geoscience 8, 937-

305 U967.

Bopp, L., Le Quere, C., Heimann, M., Manning, A.C., Monfray, P., 2002. Climate-induced oceanic oxygen fluxes: Implications for the contemporary carbon budget. Global Biogeochemical Cycles 16, 1-13.

Brandt, P., Bange, H.W., Banyte, D., Dengler, M., Didwischus, S.H., Fischer, T., Greatbatch, R.J., Hahn, J., Kanzow, T., Karstensen, J., Krortzinger, A., Krahmann, G., Schmidtko, S., Stramma, L., Tanhua, T., Visbeck, M., 2015. On the role of

310 circulation and mixing in the ventilation of oxygen minimum zones with a focus on the eastern tropical North Atlantic. Biogeosciences 12, 489-512.

Breitburg, D., Levin, L.A., Oschlies, A., Gregoire, M., Chavez, F.P., Conley, D.J., Garcon, V., Gilbert, D., Gutierrez, D., Isensee, K., Jacinto, G.S., Limburg, K.E., Montes, I., Naqvi, S.W.A., Pitcher, G.C., Rabalais, N.N., Roman, M.R., Rose, K.A., Seibel, B.A., Telszewski, M., Yasuhara, M., Zhang, J., 2018. Declining oxygen in the global ocean and coastal waters.

315 Science 359.

Brewer, P.G., Peltzer, E.T., 2016. Ocean chemistry, ocean warming, and emerging hypoxia: Commentary. Journal of Geophysical Research: Oceans 121, 3659-3667.

Busecke, J.J.M., Resplandy, L., Dunne, J.P.P., 2019. The Equatorial Undercurrent and the Oxygen Minimum Zone in the Pacific. Geophysical Research Letters, 6716-6725.

320 Cabre, A., Marinov, I., Bernardello, R., Bianchi, D., 2015. Oxygen minimum zones in the tropical Pacific across CMIP5 models: mean state differences and climate change trends. Biogeosciences 12, 5429-5454.

Cavan, E.L., Trimmer, M., Shelley, F., Sanders, R., 2017. Remineralization of particulate organic carbon in an ocean oxygen minimum zone. Nature communications 8, 14847.

Chen, D., Rothstein, L.M., Busalacchi, A.J., 1994. A Hybrid Vertical Mixing Scheme and Its Application to Tropical Ocean

325 Models. Journal of Physical Oceanography 24, 2156-2179.

Czeschel, R., Stramma, L., Johnson, G.C., 2012. Oxygen decreases and variability in the eastern equatorial Pacific. J Geophys Res-Oceans 117, 1-12.

Czeschel, R., Stramma, L., Schwarzkopf, F.U., Giese, B.S., Funk, A., Karstensen, J., 2011. Middepth circulation of the eastern tropical South Pacific and its link to the oxygen minimum zone. J Geophys Res-Oceans 116.

330 Duteil, O., Oschlies, A., 2011. Sensitivity of simulated extent and future evolution of marine suboxia to mixing intensity. Geophysical Research Letters 38.

Feely, R.A., Sabine, C.L., Schlitzer, R., Bullister, J.L., Mecking, S., Greeley, D., 2004. Oxygen utilization and organic carbon remineralization in the upper water column of the Pacific Ocean. Journal of Oceanography 60, 45-52.

335180.

Fiedler, P.C., Talley, L.D., 2006. Hydrography of the eastern tropical Pacific: A review. Progress in Oceanography 69, 143-

Fu, W.W., Bardin, A., Primeau, F., 2018. Tracing ventilation source of tropical pacific oxygen minimum zones with an adjoint global ocean transport model. Deep-Sea Research Part I: Oceanographic Research Papers 139, 95-103.

Garçon, V., Karstensen, J., Palacz, A., Telszewski, M., Aparco Lara, T., Breitburg, D., Chavez, F., Coelho, P., CornejoD’Ottone, M., Santos, C., Fiedler, B., Gallo, N.D., Grégoire, M., Gutierrez, D., Hernandez-Ayon, M., Isensee, K., Koslow,

340 T., Levin, L., Marsac, F., Maske, H., Mbaye, B.C., Montes, I., Naqvi, W., Pearlman, J., Pinto, E., Pitcher, G., Pizarro, O., Rose, K., Shenoy, D., Van der Plas, A., Vito, M.R., Weng, K., 2019. Multidisciplinary Observing in the World Ocean's Oxygen Minimum Zone Regions: From Climate to Fish — The VOICE Initiative. Frontiers in Marine Science 6. Gnanadesikan, A., Bianchi, D., Pradal, M.A., 2013. Critical role for mesoscale eddy diffusion in supplying oxygen to hypoxic ocean waters. Geophysical Research Letters 40, 5194-5198. 
https://doi.org/10.5194/gmd-2020-431

Preprint. Discussion started: 4 March 2021

(C) Author(s) 2021. CC BY 4.0 License.

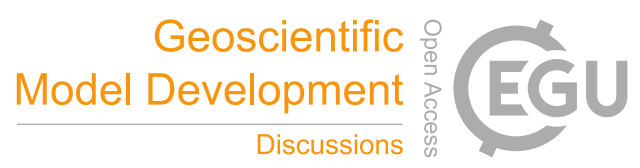

345 Kalnay, E., Kanamitsu, M., Kistler, R., Collins, W., Deaven, D., Gandin, L., Iredell, M., Saha, S., White, G., Woollen, J., Zhu, Y., Chelliah, M., Ebisuzaki, W., Higgins, W., Janowiak, J., Mo, K.C., Ropelewski, C., Wang, J., Leetmaa, A., Reynolds, R., Jenne, R., Joseph, D., 1996. The NCEP/NCAR 40-year reanalysis project. B Am Meteorol Soc 77, 437-471.

Kalvelage, T., Lavik, G., Jensen, M.M., Revsbech, N.P., Loscher, C., Schunck, H., Desai, D.K., Hauss, H., Kiko, R., Holtappels, M., LaRoche, J., Schmitz, R.A., Graco, M.I., Kuypers, M.M., 2015. Aerobic microbial respiration In oceanic

350 oxygen minimum zones. PloS one 10.

Karstensen, J., Stramma, L., Visbeck, M., 2008. Oxygen minimum zones in the eastern tropical Atlantic and Pacific oceans. Progress in Oceanography 77, 331-350.

Keller, D.P., Kriest, I., Koeve, W., Oschlies, A., 2016. Southern Ocean biological impacts on global ocean oxygen. Geophysical Research Letters 43, 6469-6477.

355 Kessler, W.S., 2006. The circulation of the eastern tropical Pacific: A review. Progress in Oceanography 69, $181-217$. Kug, J.S., Kang, I.S., An, S.I., 2003. Symmetric and antisymmetric mass exchanges between the equatorial and offequatorial Pacific associated with ENSO. Journal of Geophysical Research: Oceans 108.

Kuntz, L.B., Schrag, D.P., 2018. Hemispheric asymmetry in the ventilated thermocline of the Tropical Pacific. Journal of Climate 31, 1281-1288.

360 Levin, L.A., 2018. Manifestation, Drivers, and Emergence of Open Ocean Deoxygenation. Annual review of marine science 10, 229-260.

Libby, P.S., Wheeler, P.A., 1997. Particulate and dissolved organic nitrogen in the central and eastern equatorial Pacific.

Deep-Sea Research Part I: Oceanographic Research Papers 44, 345-361.

Llanillo, P.J., Pelegri, J.L., Talley, L.D., Pena-Izquierdo, J., Cordero, R.R., 2018. Oxygen Pathways and Budget for the

365 Eastern South Pacific Oxygen Minimum Zone. Journal of Geophysical Research: Oceans 123, $1722-1744$.

Loginova, A.N., Thomsen, S., Dengler, M., Ludke, J., Engel, A., 2019. Diapycnal dissolved organic matter supply into the upper Peruvian oxycline. Biogeosciences 16, 2033-2047.

Murtugudde, R., Seager, R., Busalacchi, A., 1996. Simulation of the tropical oceans with an ocean GCM coupled to an atmospheric mixed-layer model. Journal of Climate 9, 1795-1815.

370 Oschlies, A., Brandt, P., Stramma, L., Schmidtko, S., 2018. Drivers and mechanisms of ocean deoxygenation. Nature Geoscience 11, 467-473.

Paulmier, A., Ruiz-Pino, D., 2009. Oxygen minimum zones (OMZs) in the modern ocean. Progress in Oceanography 80, 113-128.

Raimbault, P., Slawyk, G., Boudjellal, B., Coatanoan, C., Conan, P., Coste, B., Garcia, N., Moutin, T., Pujo-Pay, M., 1999.

375 Carbon and nitrogen uptake and export in the equatorial Pacific at $150^{\circ} \mathrm{W}$ : Evidence of an efficient regenerated production cycle. Journal of Geophysical Research: Oceans 104, 3341-3356.

Schmidtko, S., Stramma, L., Visbeck, M., 2017. Decline in global oceanic oxygen content during the past five decades. Nature 542, 335-339.

Shigemitsu, M., Yamamoto, A., Oka, A., Yamanaka, Y., 2017. One possible uncertainty in CMIP5 projections of low-

380 oxygen water volume in the Eastern Tropical Pacifi. Geophysical Research Letters 31, 804-820.

Sonnerup, R.E., Mecking, S., Bullister, J.L., 2013. Transit time distributions and oxygen utilization rates in the Northeast Pacific Ocean from chlorofluorocarbons and sulfur hexafluoride. Deep-Sea Res Pt I 72, 61-71.

Stramma, L., Johnson, G.C., Firing, E., Schmidtko, S., 2010. Eastern Pacific oxygen minimum zones: Supply paths and multidecadal changes. J Geophys Res-Oceans 115.

385 Stramma, L., Johnson, G.C., Sprintall, J., Mohrholz, V., 2008. Expanding oxygen-minimum zones in the tropical oceans. Science 320, 655-658.

Stramma, L., Oschlies, A., Schmidtko, S., 2012. Mismatch between observed and modeled trends in dissolved upper-ocean oxygen over the last 50 yr. Biogeosciences 9, 4045-4057.

Talley, L.D., Feely, R.A., Sloyan, B.M., Wanninkhof, R., Baringer, M.O., Bullister, J.L., Carlson, C.A., Doney, S.C., Fine,

390 R.A., Firing, E., Gruber, N., Hansell, D.A., Ishii, M., Johnson, G.C., Katsumata, K., Key, R.M., Kramp, M., Langdon, C., Macdonald, A.M., Mathis, J.T., McDonagh, E.L., Mecking, S., Millero, F.J., Mordy, C.W., Nakano, T., Sabine, C.L.,

Smethie, W.M., Swift, J.H., Tanhua, T., Thurnherr, A.M., Warner, M.J., Zhang, J.Z., 2016. Changes in ocean heat, carbon content, and ventilation: a review of the first decade of go-ship global repeat hydrography. Annual review of marine science $8,185-215$. 
https://doi.org/10.5194/gmd-2020-431

Preprint. Discussion started: 4 March 2021

(C) Author(s) 2021. CC BY 4.0 License.

(c) (i)

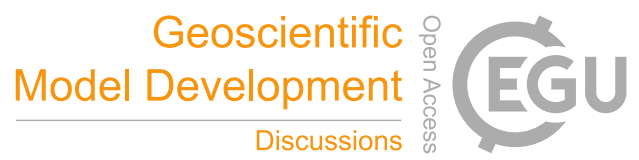

395 Tiano, L., Garcia-Robledo, E., Dalsgaard, T., Devol, A.H., Ward, B.B., Ulloa, O., Canfield, D.E., Revsbech, N.P., 2014. Oxygen distribution and aerobic respiration in the north and south eastern tropical Pacific oxygen minimum zones. Deep-Sea Research Part I: Oceanographic Research Papers 94, 173-183.

Wang, X.J., Behrenfeld, M., Le Borgne, R., Murtugudde, R., Boss, E., 2009a. Regulation of phytoplankton carbon to chlorophyll ratio by light, nutrients and temperature in the Equatorial Pacific Ocean: a basin-scale model. Biogeosciences 6,

$400 \quad 391-404$.

Wang, X.J., Le Borgne, R., Murtugudde, R., Busalacchi, A.J., Behrenfeld, M., 2008. Spatial and temporal variations in dissolved and particulate organic nitrogen in the equatorial Pacific: biological and physical influences. Biogeosciences 5, 1705-1721.

Wang, X.J., Murtugudde, R., Hackert, E., Wang, J., Beauchamp, J., 2015. Seasonal to decadal variations of sea surface

405 pCO2 and sea-air CO2 flux in the equatorial oceans over 1984-2013: A basin-scale comparison of the Pacific and Atlantic Oceans. Global Biogeochemical Cycles 29, 597-609.

Wang, X.J., Murtugudde, R., Le Borgne, R., 2009b. Nitrogen uptake and regeneration pathways in the equatorial Pacific: a basin scale modeling study. Biogeosciences 6, 2647-2660.

Wanninkhof, R., 1992. Relationship between wind speed and gas exchange over the Ocean. J Geophys Res-Oceans 97, 410 7373-7382.

Ward, B.A., Wilson, J.D., Death, R.M., Monteiro, F.M., Yool, A., Ridgwell, A., 2018. EcoGEnIE 1.0: plankton ecology in the cGEnIE Earth system model. Geoscientific Model Development 11, 4241-4267.

Weiss, R.F., 1970. The solubility of nitrogen, oxygen and argon in water and seawater. Deep-Sea Research 17, 721-735. Williams, J.H.T., Totterdell, I.J., Halloran, P.R., Valdes, P.J., 2014. Numerical simulations of oceanic oxygen cycling in the 415 FAMOUS Earth-System model: FAMOUS-ES, version 1.0. Geoscientific Model Development 7, 1419-1431. 
https://doi.org/10.5194/gmd-2020-431

Preprint. Discussion started: 4 March 2021

(c) Author(s) 2021. CC BY 4.0 License.

(c) (i)

\section{Tables}

Table 1. Model experiments with different values for remineralization rate $\left(\mathrm{C}_{\mathrm{DON}}\right)$ and vertical background diffusion $(\mathrm{Kb})$.

\begin{tabular}{|c|c|c|c|c|c|c|}
\hline Parameter & Unit & Reference & $\mathrm{Cd} 0.5$ & $\begin{array}{l}\mathrm{Cd} 0.5 \\
\mathrm{~Kb} 0.1 \\
\end{array}$ & $\begin{array}{l}\mathrm{Cd} 0.5 \\
\mathrm{~Kb} 0.3 \\
\end{array}$ & $\begin{array}{l}\mathrm{Cd} 0.5 \\
\mathrm{~Kb} 0.5 \\
\end{array}$ \\
\hline $\mathrm{C}_{\mathrm{DON}}(0-100 \mathrm{~m})$ & $\mathrm{d}^{-1}$ & 0.001 & \multicolumn{4}{|c|}{0.0005} \\
\hline $\mathrm{C}_{\text {DON }}(100-600 \mathrm{~m})$ & & $0.001-0.0005$ & \multicolumn{4}{|c|}{$0.0005-0.00025$} \\
\hline $\mathrm{C}_{\mathrm{DON}}(600-1000 \mathrm{~m})$ & & 0.0005 & \multicolumn{4}{|c|}{0.00025} \\
\hline $\mathrm{Kb}$ & $\mathrm{cm}^{2} \mathrm{~s}^{-1}$ & 0 & 0 & 0.1 & 0.3 & 0.5 \\
\hline
\end{tabular}

Table 2. Statistics for DO $\left(\mathrm{mmol} \mathrm{m}^{-3}\right)$ comparisons between WOA2013 and model experiments over 1981-2000 in the Eastern Tropical North Pacific (ETNP) and Eastern Tropical South Pacific (ETSP).

\begin{tabular}{|c|c|c|c|c|c|c|c|c|c|c|c|}
\hline \multirow{2}{*}{ Layers } & \multirow{2}{*}{ Statistics } & \multicolumn{5}{|c|}{$\operatorname{ETNP}\left(165^{\circ} \mathrm{W}-90^{\circ} \mathrm{W}, 5^{\circ} \mathrm{N}-20^{\circ} \mathrm{N}\right)$} & \multicolumn{5}{|c|}{$\operatorname{ETSP}\left(110^{\circ} \mathrm{W}-80^{\circ} \mathrm{W}, 10^{\circ} \mathrm{S}-3^{\circ} \mathrm{S}\right)$} \\
\hline & & Reference & $\mathrm{Cd} 0.5$ & $\begin{array}{l}\mathrm{Cd} 0.5 \\
\mathrm{~Kb} 0.1\end{array}$ & $\begin{array}{l}\mathrm{Cd} 0.5 \\
\mathrm{~Kb} 0.3\end{array}$ & $\begin{array}{l}\mathrm{Cd} 0.5 \\
\mathrm{~Kb} 0.5\end{array}$ & Reference & $\mathrm{Cd} 0.5$ & $\begin{array}{l}\mathrm{Cd} 0.5 \\
\mathrm{~Kb} 0.1\end{array}$ & $\begin{array}{l}\mathrm{Cd} 0.5 \\
\mathrm{~Kb} 0.3\end{array}$ & $\begin{array}{l}\mathrm{Cd} 0.5 \\
\mathrm{~Kb} 0.5\end{array}$ \\
\hline \multirow{3}{*}{$\begin{array}{c}200-400 \\
(\mathrm{~m})\end{array}$} & Bias & -9.45 & -4.00 & -3.96 & -3.82 & -3.60 & -11.89 & -3.59 & -3.33 & -2.67 & -1.84 \\
\hline & MAE & 15.17 & 15.70 & 15.56 & 15.27 & 14.98 & 11.89 & 3.72 & 3.55 & 3.15 & 3.12 \\
\hline & RMSE & 19.01 & 17.34 & 17.18 & 16.82 & 16.44 & 12.18 & 4.44 & 4.28 & 3.92 & 3.57 \\
\hline \multirow{3}{*}{$\begin{array}{c}400-700 \\
(\mathrm{~m})\end{array}$} & Bias & -7.24 & -4.99 & -4.19 & -2.49 & -0.72 & -10.36 & -7.17 & -5.79 & -2.92 & -0.04 \\
\hline & MAE & 9.01 & 8.25 & 7.99 & 7.44 & 6.95 & 10.38 & 7.99 & 7.12 & 5.59 & 4.85 \\
\hline & RMSE & 10.86 & 9.72 & 9.29 & 8.48 & 7.88 & 12.33 & 9.61 & 8.54 & 6.75 & 5.88 \\
\hline \multirow{3}{*}{$\begin{array}{c}700-1000 \\
(\mathrm{~m})\end{array}$} & Bias & -7.19 & -4.49 & -2.44 & 1.08 & 3.98 & -12.90 & -9.11 & -6.48 & -2.34 & 0.78 \\
\hline & MAE & 7.18 & 4.67 & 4.12 & 4.17 & 5.28 & 13.33 & 10.42 & 8.81 & 6.98 & 6.47 \\
\hline & RMSE & 9.22 & 6.85 & 5.49 & 4.67 & 5.92 & 16.14 & 12.81 & 10.79 & 8.33 & 7.59 \\
\hline
\end{tabular}

425

Table 3. Comparisons of OMZ volume $\left(10^{15} \mathrm{~m}^{3}\right)$ between WOA2013 and sensitivity experiments.

\begin{tabular}{|c|c|c|c|c|c|c|c|}
\hline Regions & Waters & WOA2013 & Reference & $\mathrm{Cd} 0.5$ & $\begin{array}{l}\mathrm{Cd} 0.5 \\
\mathrm{~Kb} 0.1 \\
\end{array}$ & $\begin{array}{l}\mathrm{Cd} 0.5 \\
\mathrm{~Kb} 0.3 \\
\end{array}$ & $\begin{array}{l}\mathrm{Cd} 0.5 \\
\mathrm{~Kb} 0.5 \\
\end{array}$ \\
\hline \multirow{2}{*}{ North Pacific } & Suboxic & 5.97 & 10.47 & 8.87 & 8.29 & 7.36 & 6.61 \\
\hline & Hypoxic & 19.98 & 21.21 & 20.48 & 20.35 & 20.01 & 19.62 \\
\hline \multirow{2}{*}{ South Pacific } & Suboxic & 1.43 & 3.49 & 2.42 & 2.20 & 1.85 & 1.56 \\
\hline & Hypoxic & 7.12 & 9.90 & 8.73 & 8.35 & 7.70 & 7.13 \\
\hline
\end{tabular}

Suboxic: DO $<20 \mathrm{mmol} \mathrm{m}^{-3}$; Hypoxic: DO $<60 \mathrm{mmol} \mathrm{m}^{-3}$. 


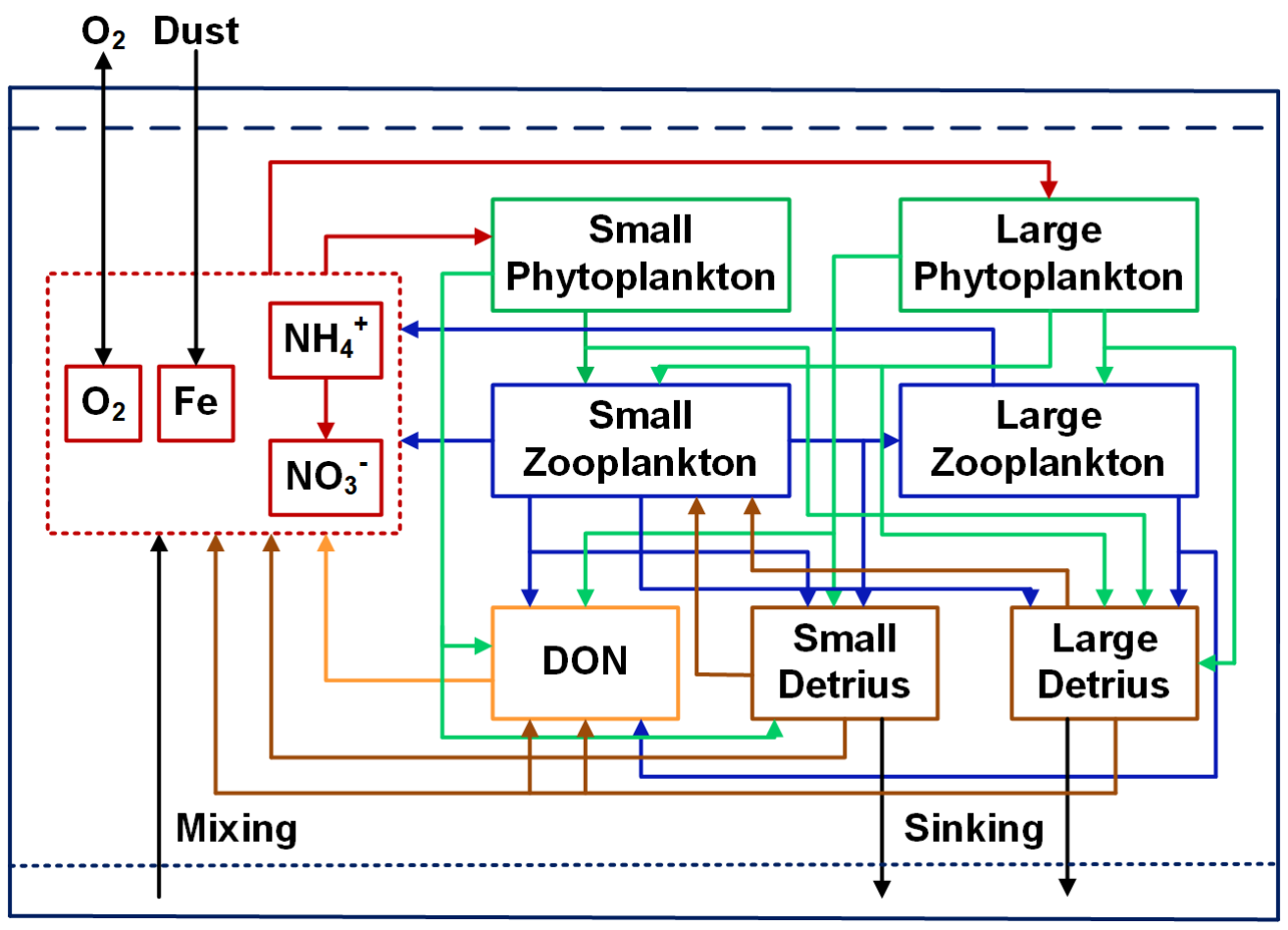

Figure 1. Flow diagram of ecosystem model. Red, green, blue, yellow and brown lines and arrows denote fluxes originating from inorganic forms, phytoplankton, zooplankton, DON and detritus, respectively. 


\section{WOA2013}
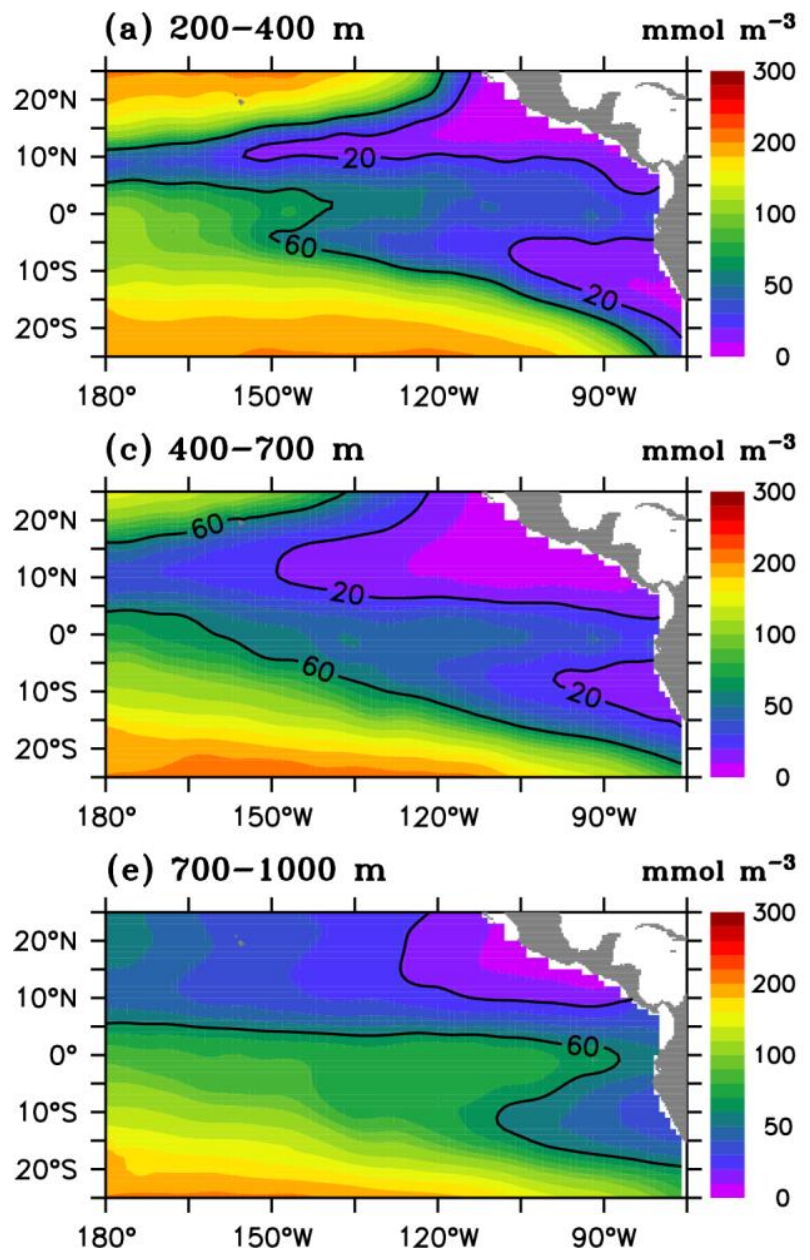

\section{Reference}

(b) 200-400 m

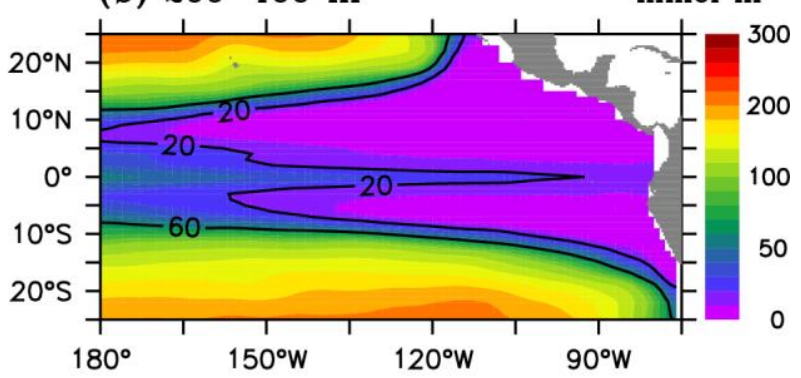

(d) 400-700 m

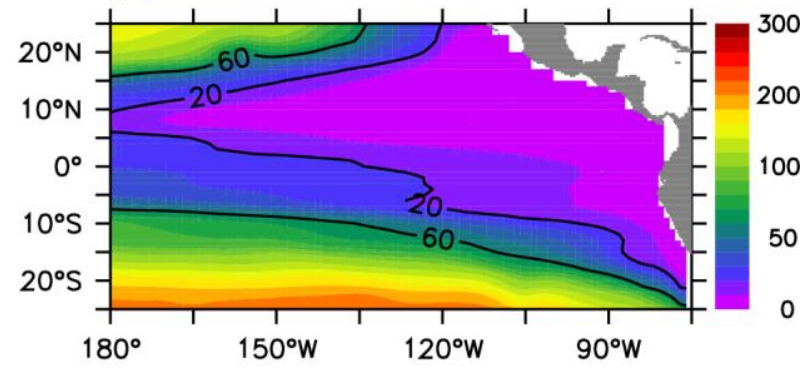

(f) $700-1000 \mathrm{~m}$

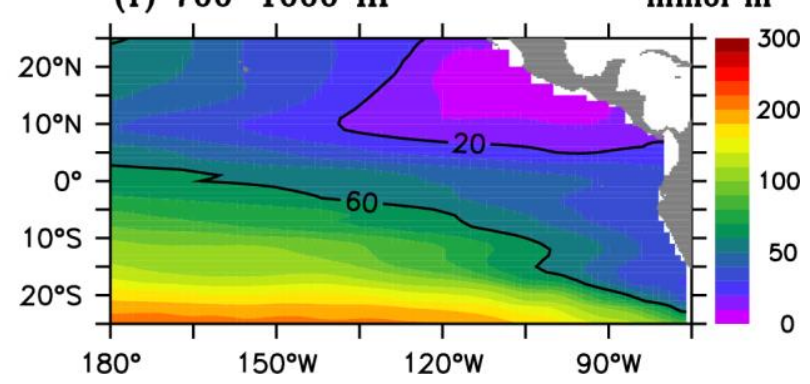

Figure 2. Comparisons of DO concentration between WOA2013 (left panel) and reference run during 1981-2000 (right 440 panel). 
(a) DON (mmol N m$\left.{ }^{-3}\right)$

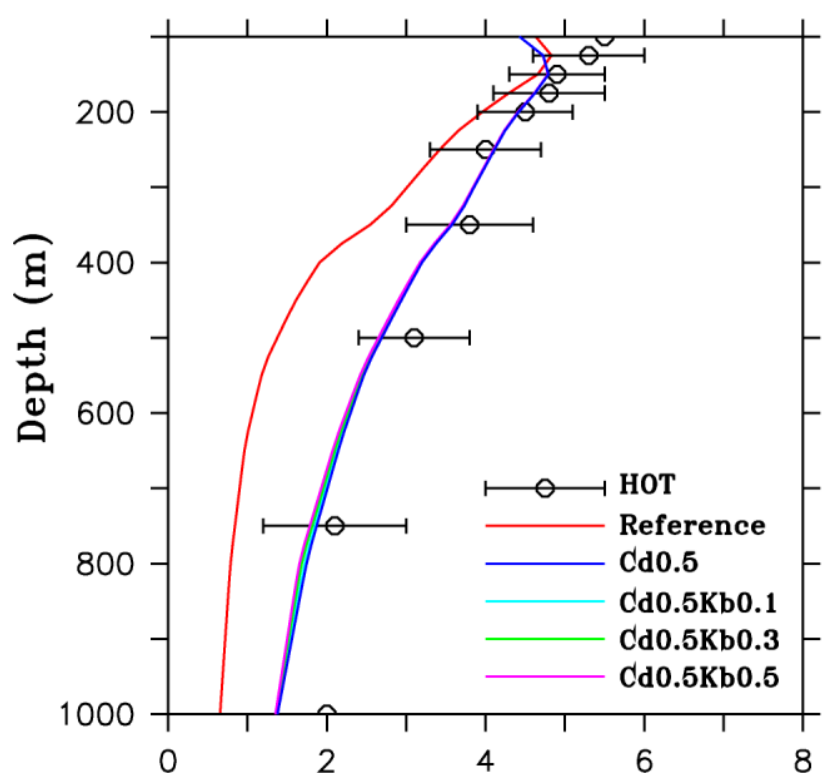

(b) Consumption ( $\mathrm{mmol} \mathrm{m}^{-3} \mathrm{yr}^{-1}$ )

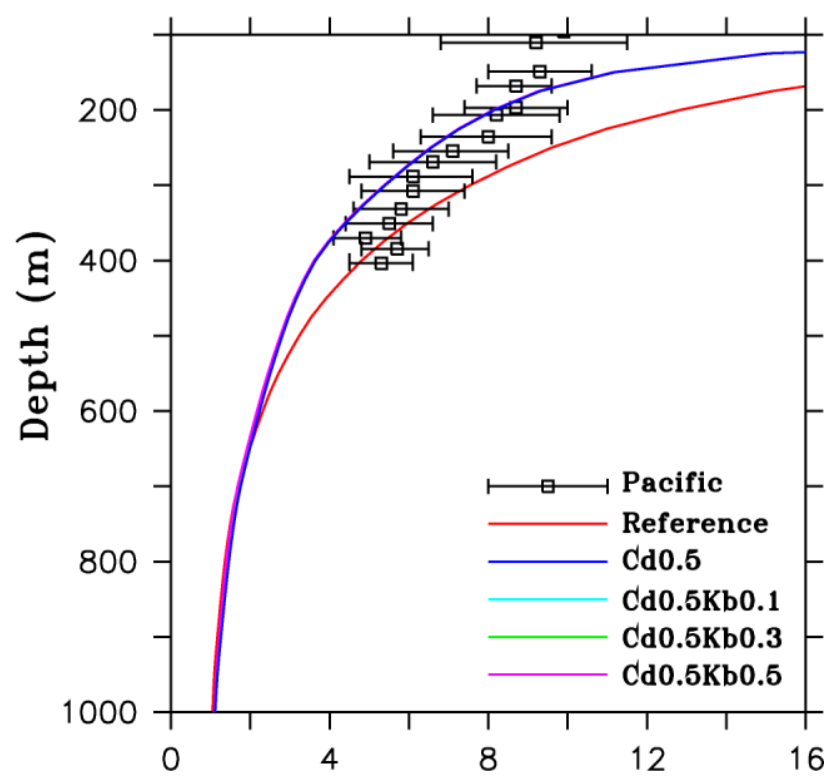

445 Figure 3. Comparisons of DON concentration (a) and consumption rate (b) between observation and model experiments.

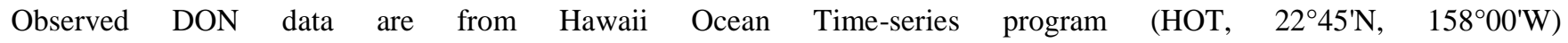
(https://hahana.soest.hawaii.edu/hot/hot_jgofs.html). Observed consumption data are obtained from Karastensen et al., (2008) for the entire Pacific. 
(a) WOA2013

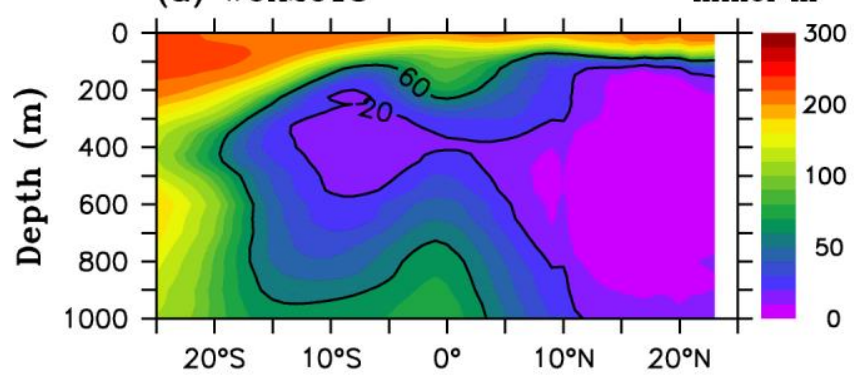

(c) $\mathrm{Cd} 0.5$

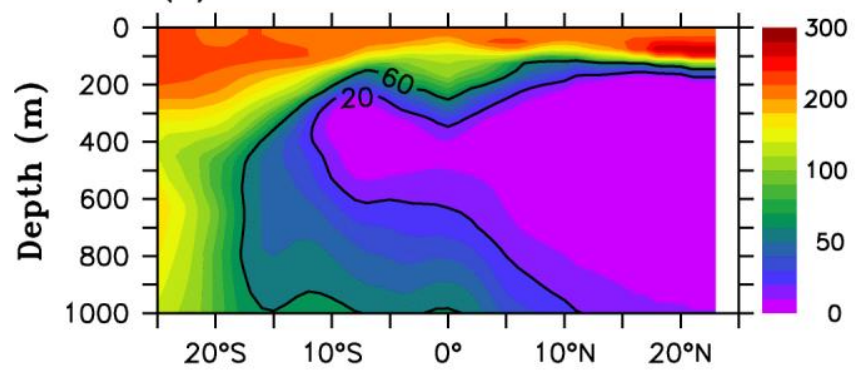

(e) $\mathrm{Cd} 0.5 \mathrm{~Kb} 0.3$

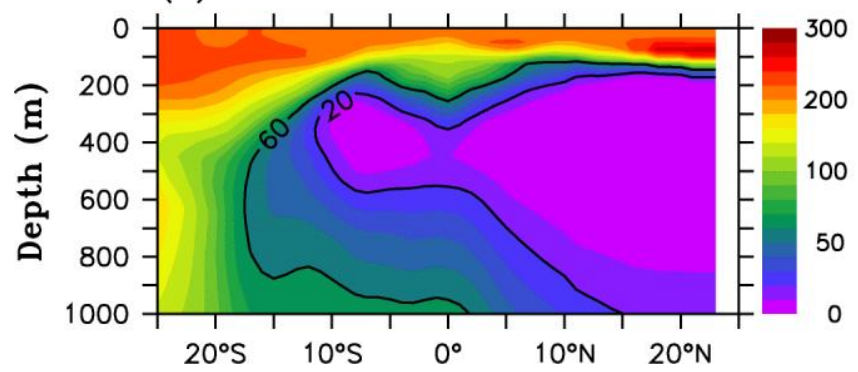

(b) Reference

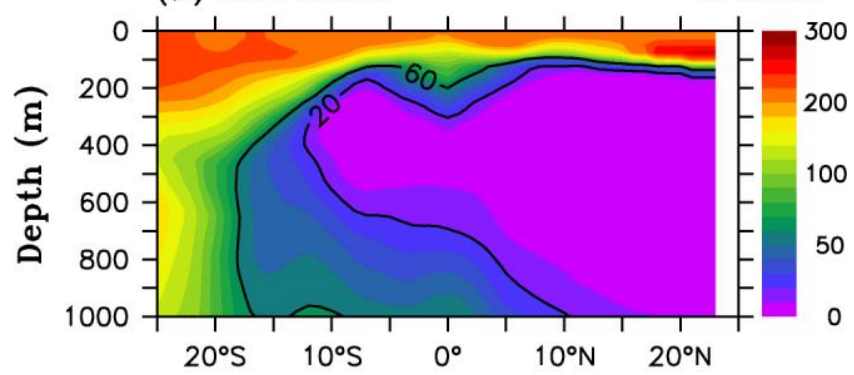

(d) $\mathrm{Cd} 0.5 \mathrm{~Kb} 0.1$

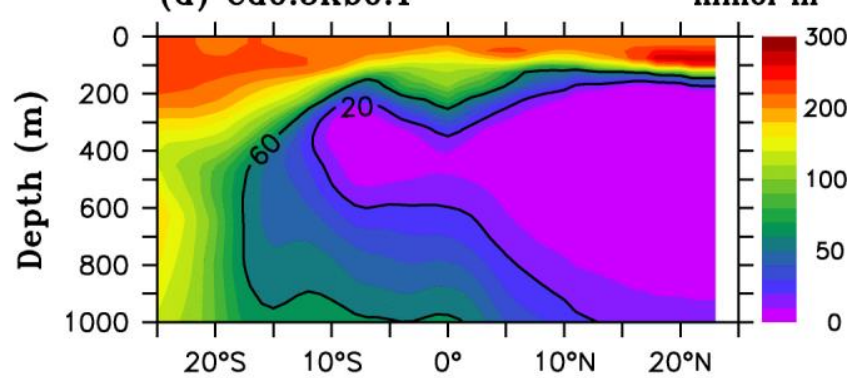

(f) $\mathrm{Cd} 0.5 \mathrm{~Kb} 0.5$

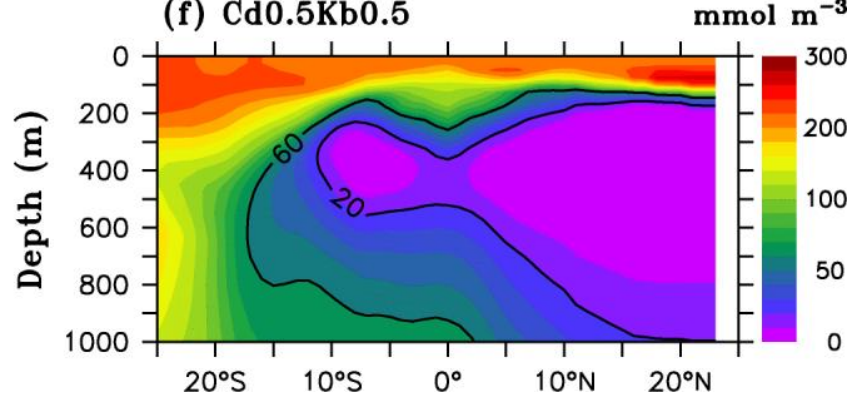

Figure 4. Observed and simulated DO from model experiments over $110^{\circ} \mathrm{W}-85^{\circ} \mathrm{W}$. (a) WOA2013, (b) reference run, (c) Cd0.5, (d) Cd0.5Kb0.1, (e) Cd0.5Kb0.3, and (f) Cd0.5Kb0.5 over 1981-2000. 
ETNP
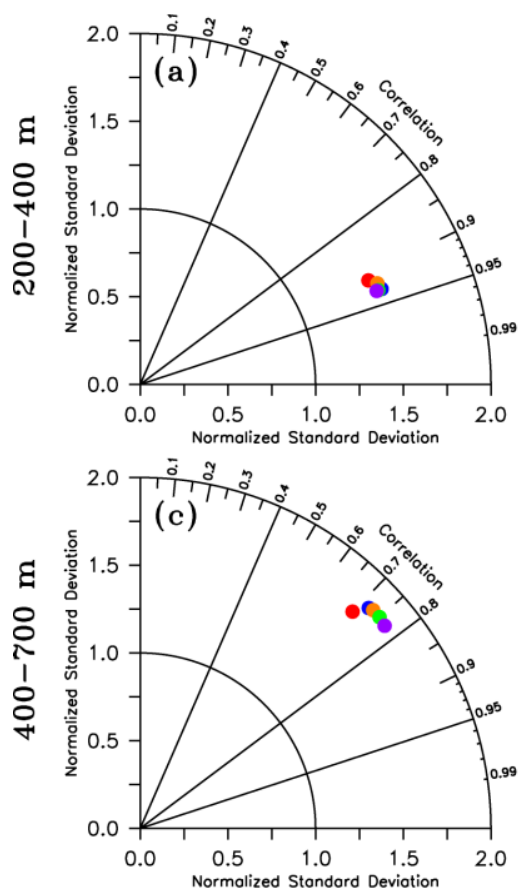

455

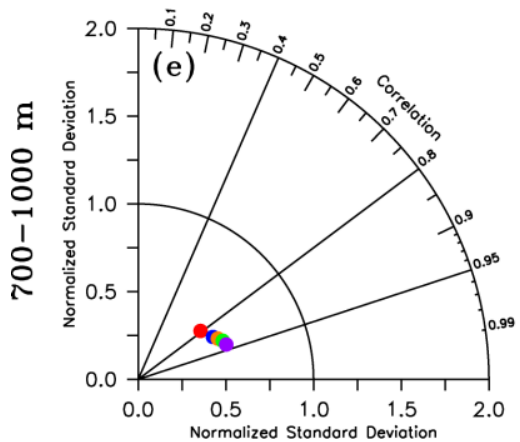

\section{ETSP}
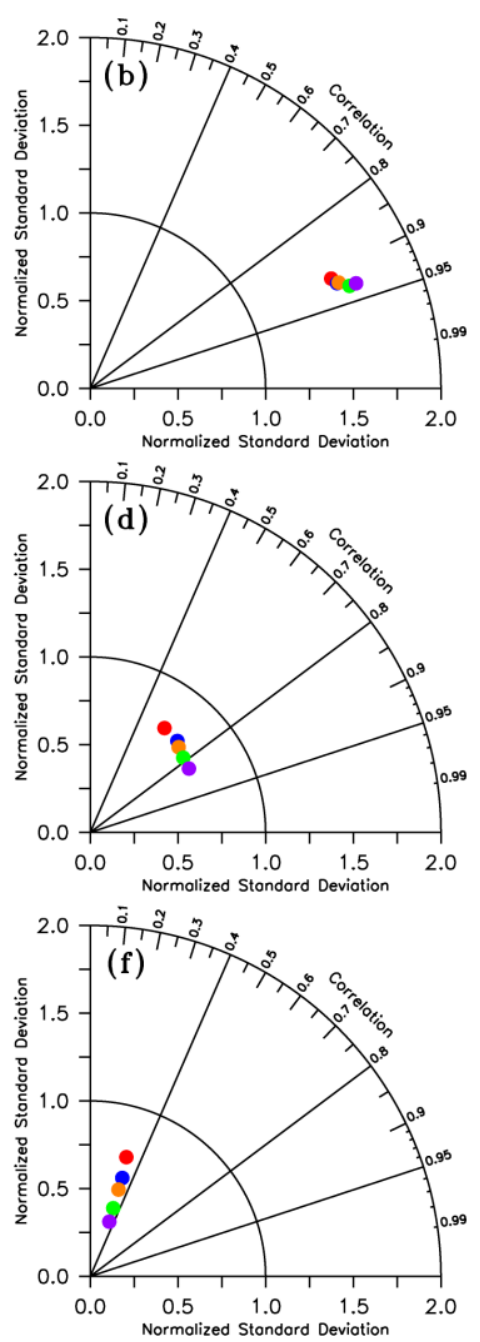

Reference

- Cd0.5

- $\mathrm{Cd} 0.5 \mathrm{~Kb} 0.1$

- $\mathrm{Cd} 0.5 \mathrm{~Kb} 0.3$

Cd0.5Kb0.5

Figure 5. Taylor diagrams performed on the simulation of DO concentration between WOA2013 and model experiments for the left panel (ETNP: $165^{\circ} \mathrm{W}-90^{\circ} \mathrm{W}, 5^{\circ} \mathrm{N}-20^{\circ} \mathrm{N}$ ) and right panel (ETSP: $110^{\circ} \mathrm{W}-80^{\circ} \mathrm{W}, 10^{\circ} \mathrm{S}-3^{\circ} \mathrm{S}$ ) over $200-400 \mathrm{~m}, 400-700$ $\mathrm{m}$, and $700-1000 \mathrm{~m}$. 


\section{Cruise data}

(a) $10^{\circ} \mathrm{N}, 19890402-19890519 \mathrm{mmol} \mathrm{m}^{-3}$

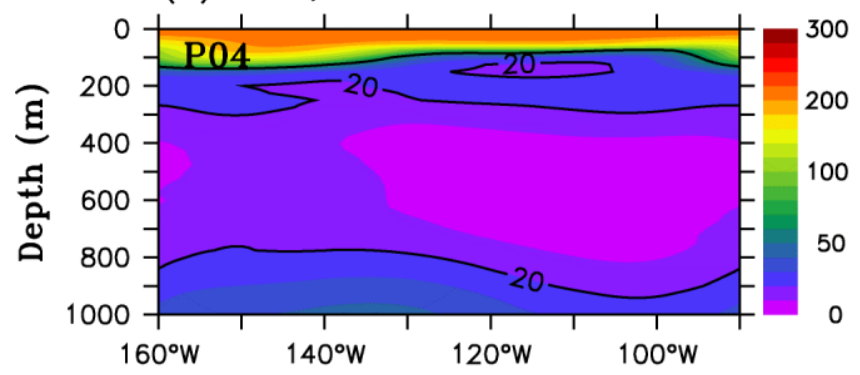

(c) $17^{\circ} \mathrm{S}, 19940327-19940625 \mathrm{mmol} \mathrm{m}^{-3}$

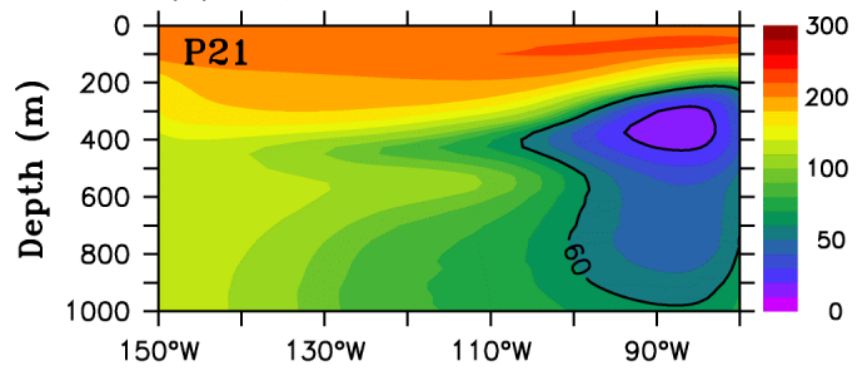

(e) $17^{\circ} \mathrm{S}, 20090410-20090519 \mathrm{mmol} \mathrm{m}^{-3}$

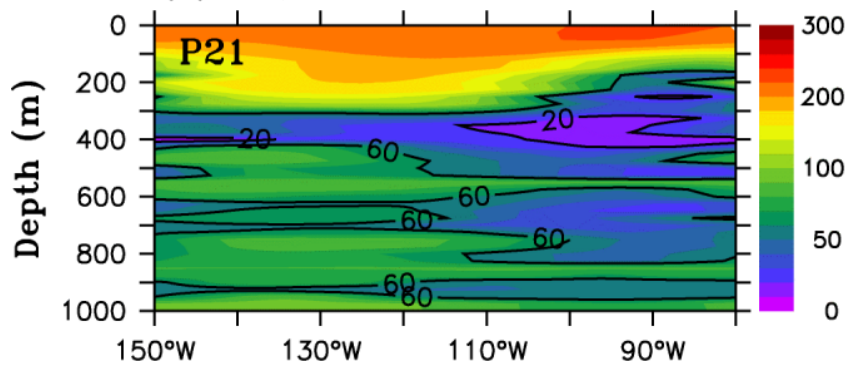

Model (Cd0.5Kb0.5)

(b) $10^{\circ} \mathrm{N}, 198904-198905 \mathrm{mmol} \mathrm{m} \mathrm{m}^{-3}$

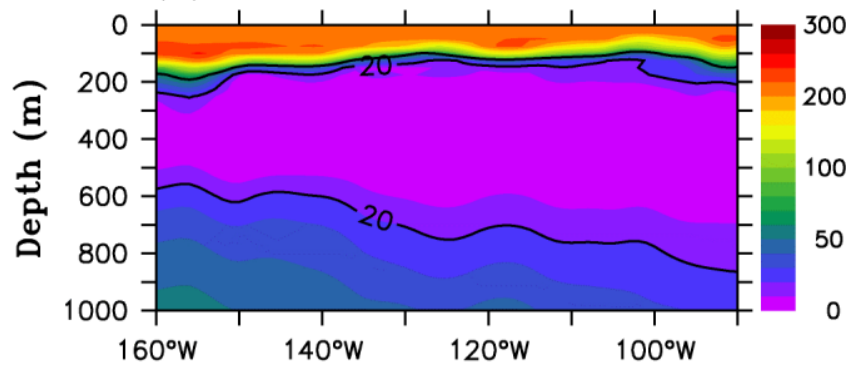

(d) $17^{\circ} \mathrm{S}, 199403-199406 \mathrm{mmol} \mathrm{m}$

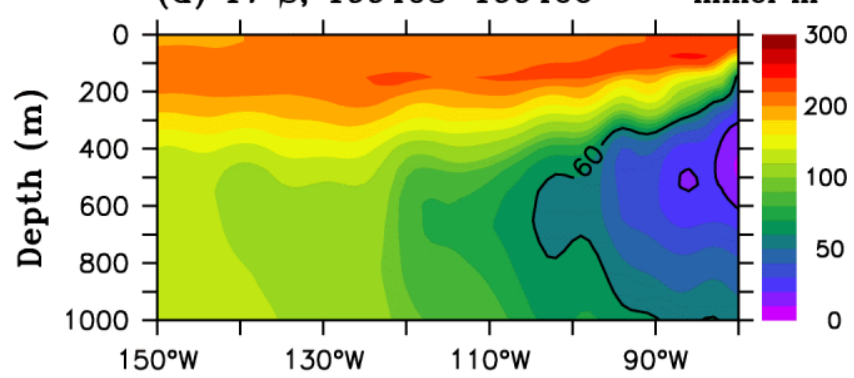

(f) $17^{\circ} \mathrm{S}, 200904-200905$ $\mathrm{mmol} \mathrm{m}^{-3}$

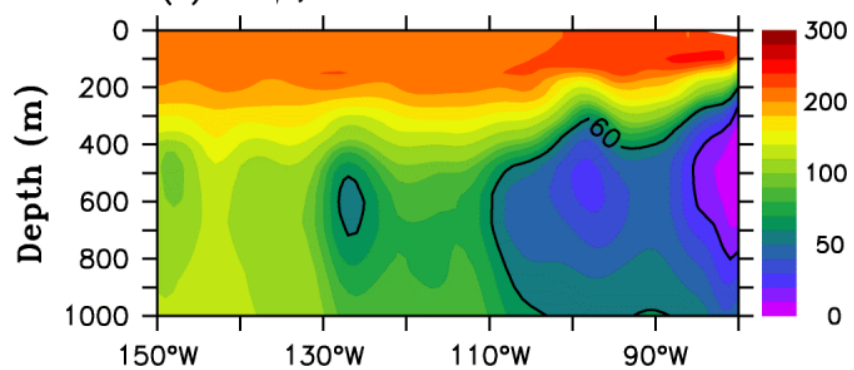

Figure 6. Distribution of DO from cruise data (left panel) and model results (right panel). Observed DO along the P04 and P21 lines are from CCHDO (https://cchdo.ucsd.edu/), which provides access to high quality global CTD and hydrographic data from GO-SHIP, WOCE, CLIVAR and other repeat hydrography programs. 
Cd0.5Kb0.5-CD0.5

(a) $200-400 \mathrm{~m}$

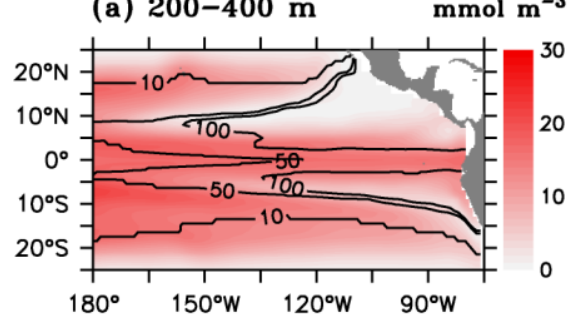

(d) $400-700 \mathrm{~m}$

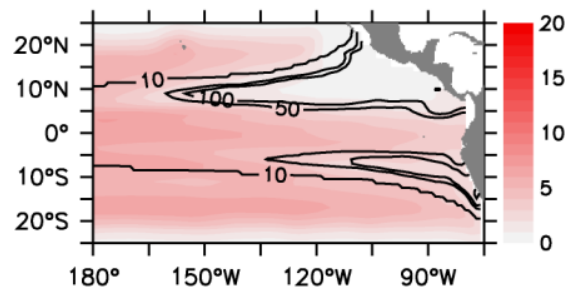

(h) 700-1000 m

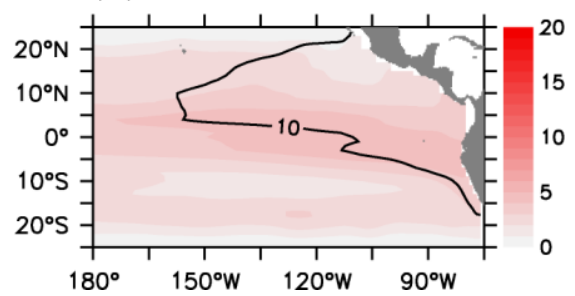

(b) $200-400 \mathrm{~m}$

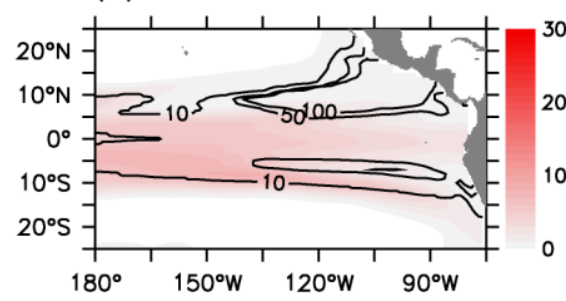

(e) $400-700 \mathrm{~m}$

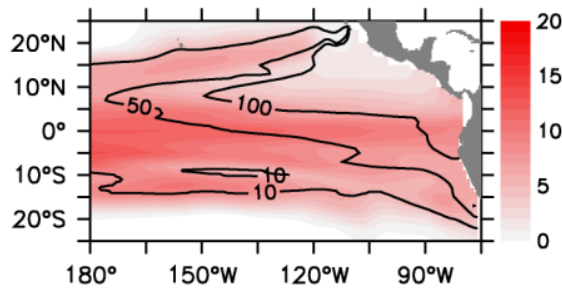

(i) $700-1000 \mathrm{~m}$

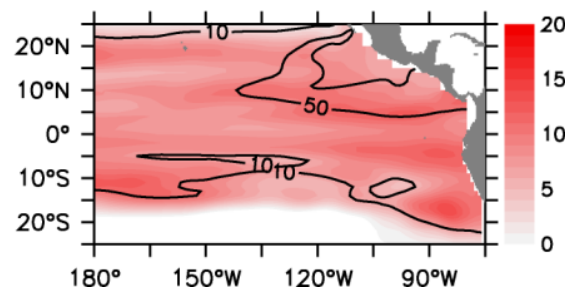

Cd0.5Kb0.5-Reference

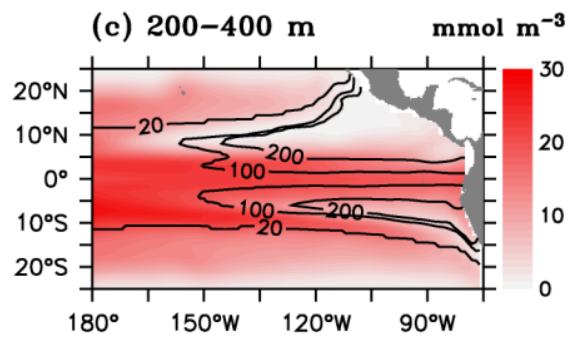

(f) $400-700 \mathrm{~m}$

$\mathrm{mmol} \mathrm{m}^{-3}$

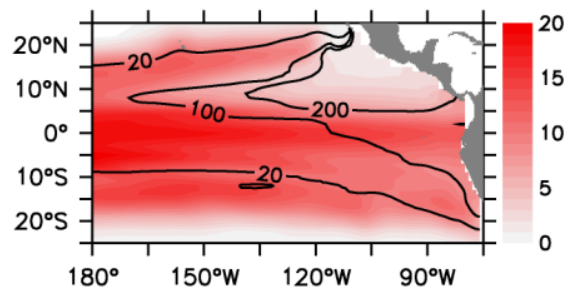

(j) $700-1000 \mathrm{~m}$

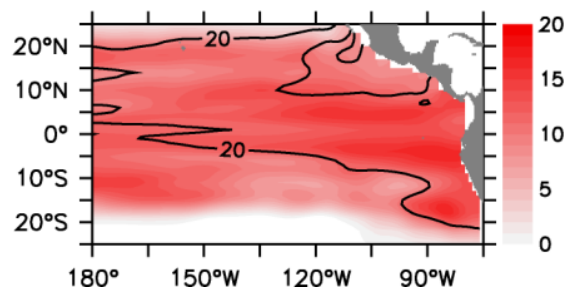

Figure 7. Changes of DO concentration due to reduced remineralization rate (left panel, Cd0.5 minus reference), enhanced mixing (middle panel, $\mathrm{Cd} 0.5 \mathrm{~Kb} 0.5$ minus $\mathrm{Cd} 0.5$ ), and their combination (right panel, $\mathrm{Cd} 0.5 \mathrm{~Kb} 0.5$ minus reference).

Superimposed solid black lines denote the percentage of DO change relative to the reference run contoured by $10 \%, 50 \%$ and $100 \%$ in the left and middle panel, and $20 \%, 100 \%$ and $200 \%$ in the right panel. 


\section{Consumption (Cd0.5-Reference)}

(a) $200-400 \mathrm{~m} \quad \mathrm{mmol} \mathrm{m}^{-3} \mathrm{yr}^{-1}$

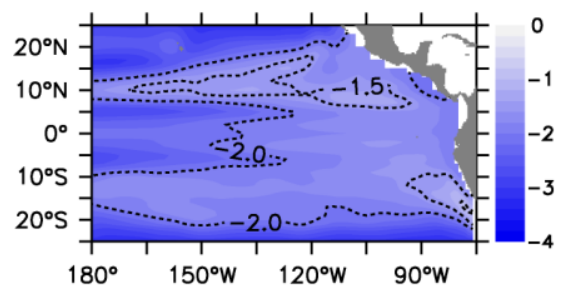

(d) $400-700 \mathrm{~m} \quad \mathrm{mmol} \mathrm{m}^{-3} \mathrm{yr}^{-1}$

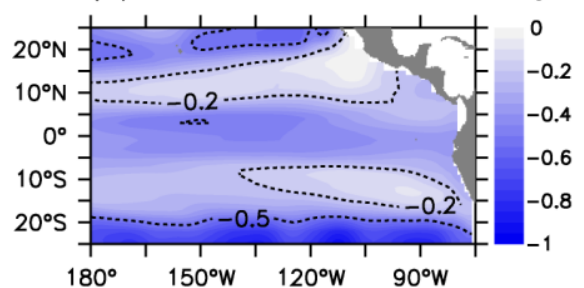

(h) 700-1000 m $\mathrm{mmol} \mathrm{m}^{-3} \mathrm{yr}^{-1}$

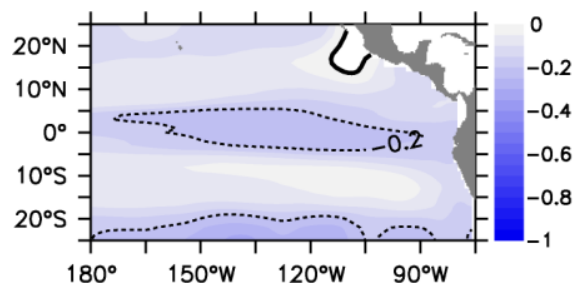

Supply

(Cd0.5Kb0.5-Cd0.5)

(b) $200-400 \mathrm{~m} \quad \mathrm{mmol} \mathrm{m}^{-3} \mathrm{yr}^{-1}$

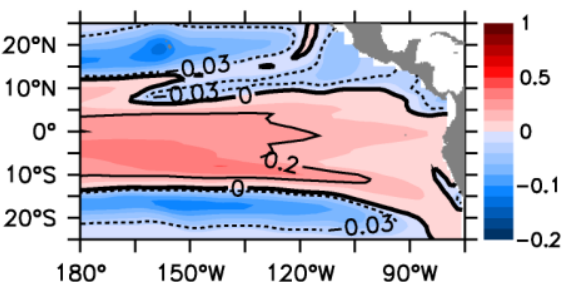

(e) $400-700 \mathrm{~m} \quad \mathrm{mmol} \mathrm{m}^{-3} \mathrm{yr}^{-1}$

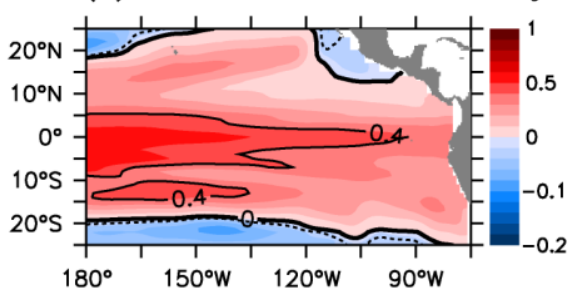

(i) $700-1000 \mathrm{~m} \quad \mathrm{mmol} \mathrm{m}^{-3} \mathrm{yr}^{-1}$

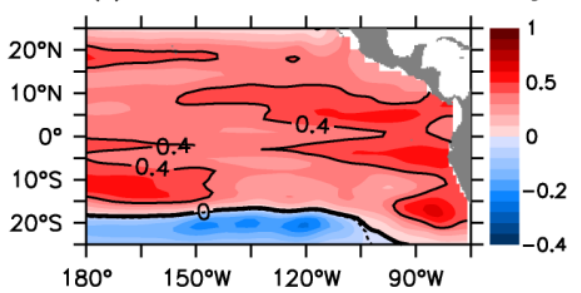

Consumption (Cd0.5Kb0.5-Cd0.5)

(c) $200-400 \mathrm{~m} \quad \mathrm{mmol} \mathrm{m}^{-3} \mathrm{yr}^{-1}$

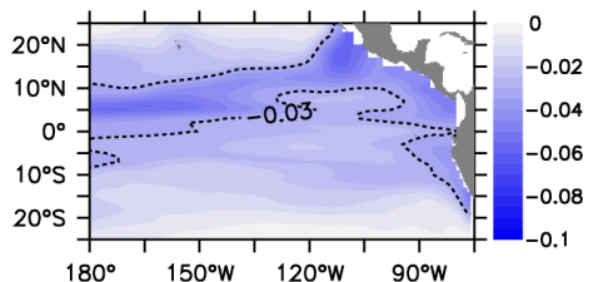

(f) $400-700 \mathrm{~m} \quad \mathrm{mmol} \mathrm{m}^{-3} \mathrm{yr}^{-1}$

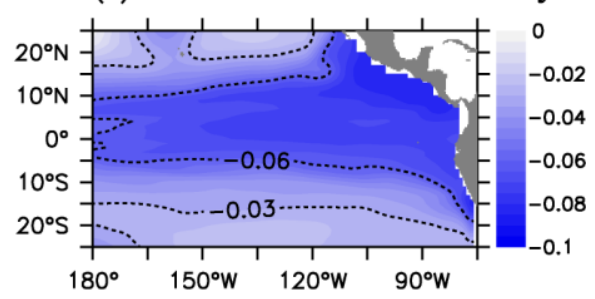

(j) 700-1000 m $\mathrm{mmol} \mathrm{m}^{-3} \mathrm{yr}^{-1}$

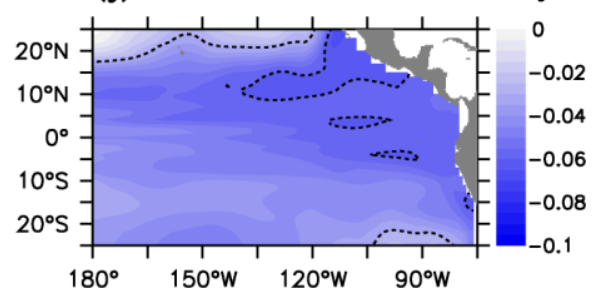

Figure 8. Decrease of DO consumption due to reduced remineralization rate (left panel, Cd0.5 minus reference), and changes in DO supply (middle panel, $\mathrm{Cd} 0.5 \mathrm{~Kb} 0.5$ minus $\mathrm{Cd} 0.5$ ) and decrease of DO consumption due to enhanced mixing (right panel, Cd0.5Kb0.5 minus Cd0.5). 


\section{$110^{\circ} \mathrm{W}-85^{\circ} \mathrm{W}$}

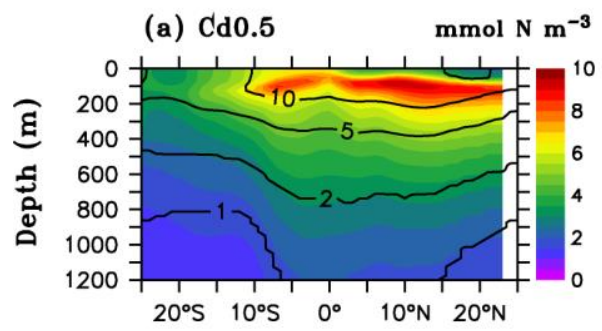

(d) Cd0.5Kb0.5

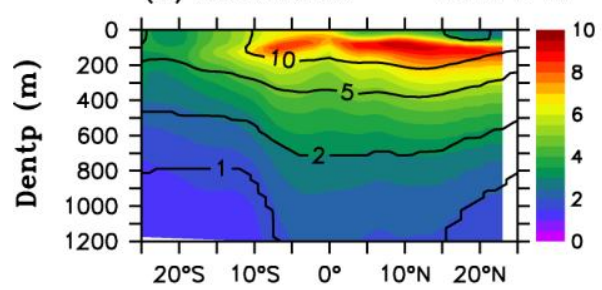

(h) Difference

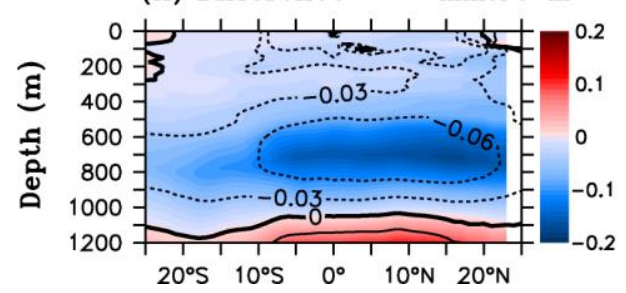

$5^{\circ} \mathrm{N}-20^{\circ} \mathrm{N}$

(b) Cd0.5

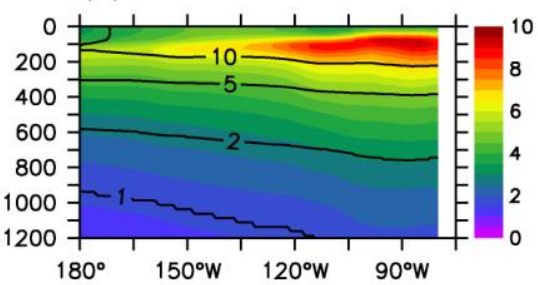

(e) $\mathrm{Cd} 0.5 \mathrm{~Kb} 0.5 \quad \mathrm{mmol} \mathrm{N} \mathrm{m}{ }^{-3}$

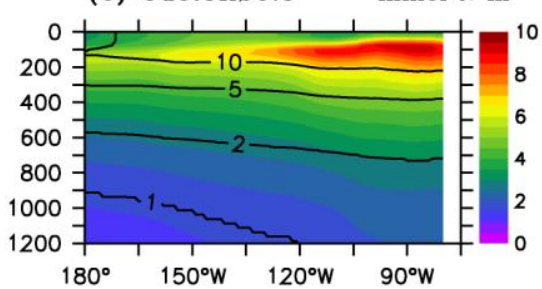

(i) Difference $\quad \mathrm{mmol} \mathrm{N} \mathrm{m}^{-3}$

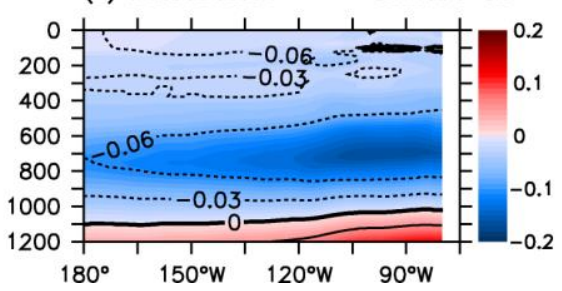

$$
10^{\circ} \mathrm{S}-3^{\circ} \mathrm{S}
$$

(c) $\mathrm{Cd} 0.5$

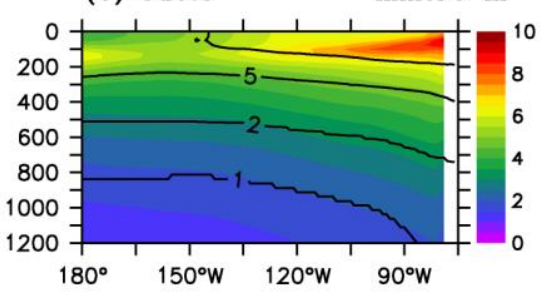

(f) Cd0.5Kb0.5

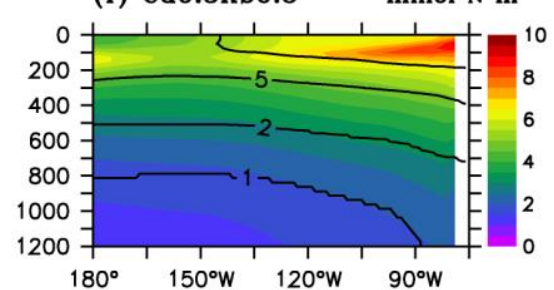

(j) Difference $\mathrm{mmol} \mathrm{N} \mathrm{m}^{-3}$

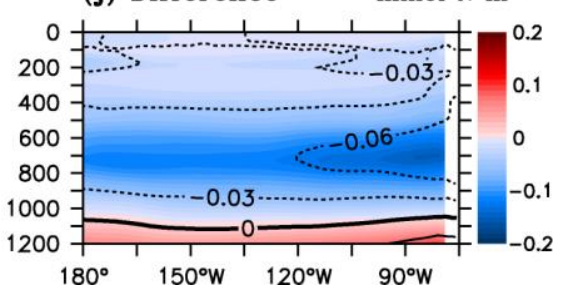

Figure 9. Distribution of DON and DON remineralization $\left(\mathrm{mmol} \mathrm{m} \mathrm{mr}^{-3}\right.$ ) over $110^{\circ} \mathrm{W}-85^{\circ} \mathrm{W}$ (left panel), $5^{\circ} \mathrm{N}-20^{\circ} \mathrm{N}($ middle panel), and $10^{\circ} \mathrm{S}-3^{\circ} \mathrm{S}$ (right panel) from (a-c) $\mathrm{Cd} 0.5$, (d-f) $\mathrm{Cd} 0.5 \mathrm{~Kb} 0.5$, and (e-f) their differences (Cd0.5Kb0.5 minus $\left.\mathrm{Cd} 0.5\right)$. Superimposed black lines denote consumption rate $\left(\mathrm{mmol} \mathrm{m}^{-3} \mathrm{yr}^{-1}\right)$ by remineralization of DON in (a-f) and the difference of consumption rate between $\mathrm{Cd} 0.5 \mathrm{~Kb} 0.5$ and $\mathrm{Cd} 0.5$ in $(\mathbf{h}-\mathbf{j})$. 
https://doi.org/10.5194/gmd-2020-431

Preprint. Discussion started: 4 March 2021

(c) Author(s) 2021. CC BY 4.0 License.

\section{(c) (i)}

(Cd0.5Kb0.5-Cd0.5)

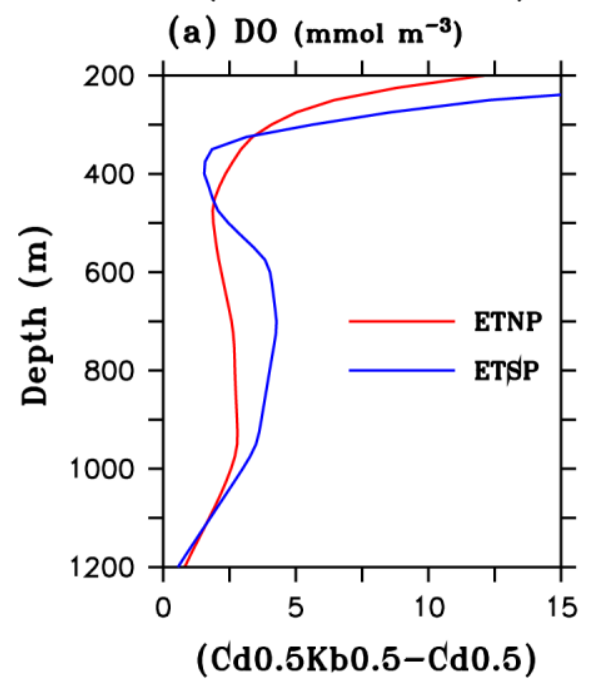

(c) Supply (mmol m $\left.\mathrm{mr}^{-3} \mathrm{yr}^{-1}\right)$

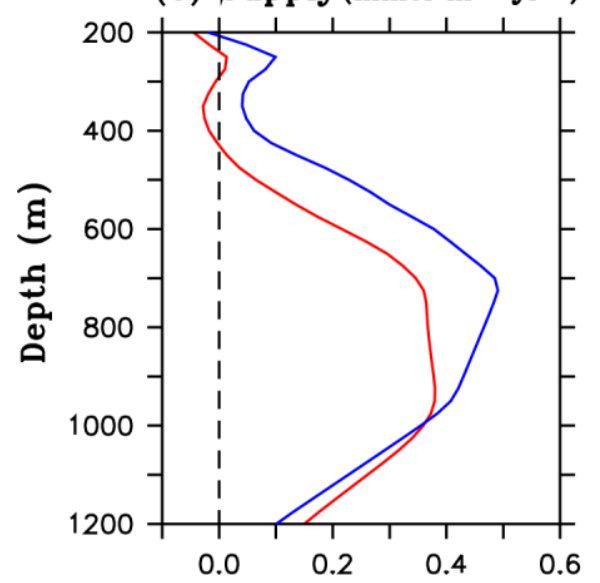

(b) $\mathrm{DO}\left(\mathrm{mmol} \mathrm{m}^{-3}\right)$

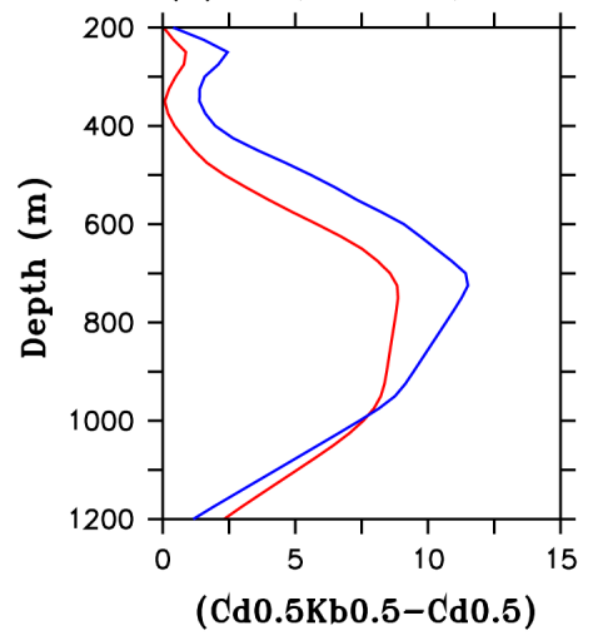

(d) Consum ( $\left.\mathrm{mmol} \mathrm{m}^{-3} \mathrm{yr}^{-1}\right)$

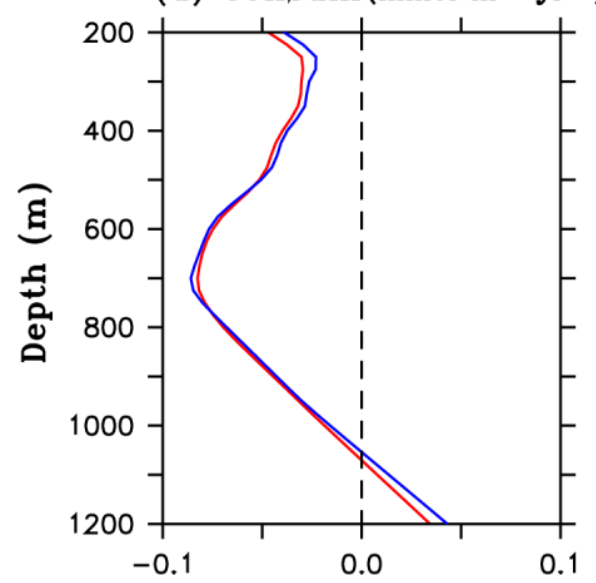

Figure 10. Changes due to reduced remineralization rate ( $\mathrm{Cd} 0.5$ minus reference) for (a) $\mathrm{DO}$, and enhanced mixing $(\mathrm{Cd} 0.5 \mathrm{~Kb} 0.5$ minus $\mathrm{Cd} 0.5)$ for (b) DO, (c) physical supply, and (d) biological consumption. ETNP: $165^{\circ} \mathrm{W}-90^{\circ} \mathrm{W}, 5^{\circ} \mathrm{N}-$ $20^{\circ} \mathrm{N}$; ETSP: $110^{\circ} \mathrm{W}-80^{\circ} \mathrm{W}, 10^{\circ} \mathrm{S}-3^{\circ} \mathrm{S}$. 


\section{Appendix A}

\section{Model biogeochemical equations}

\section{Phytoplankton equations}

$$
\begin{aligned}
500 \frac{\partial P_{S}}{\partial t} & =\mu_{S} P_{S}-g_{P_{S}}\left(1-e^{-\Lambda P_{S}}\right) Z_{S}-m_{S} P_{S} \\
\frac{\partial P_{L}}{\partial t} & =\mu_{L} P_{L}-g_{P_{L} 1}\left(1-e^{-\Lambda P_{L}}\right) Z_{L}-g_{P_{L} 2}\left(1-e^{-\Lambda P_{L}}\right) Z_{S}-m_{L} P_{L}
\end{aligned}
$$

\section{Zooplankton equations}

$\frac{\partial Z_{S}}{\partial t}=\left[\lambda\left(g_{P_{S}}\left(1-e^{-\Lambda P S}\right)+g_{P_{L^{2}}}\left(1-e^{-\Lambda P_{L}}\right)\right)+g_{D_{S}}\left(1-e^{-\Lambda D_{S}}\right)+g_{D_{L} 2}\left(1-e^{-\Lambda D_{L}}\right)-\left(r_{S}+\delta_{S}\right)\right] Z_{S}-g_{Z_{S}}\left(1-e^{-\Lambda Z_{S}}\right) Z_{L}$

$\frac{\partial Z_{L}}{\partial t}=\left[\lambda\left(g_{P_{L} 1}\left(1-e^{-\Lambda P_{L}}\right)+g_{Z_{S}}\left(1-e^{-\Lambda Z_{S}}\right)\right)+g_{D_{L} 1}\left(1-e^{-\Lambda D_{L}}\right)-\left(r_{L}+\delta_{L}\right)\right] Z_{L}$

\section{Detritus equations}

$\frac{\partial D_{S}}{\partial t}=\left(m_{S} P_{S}+m_{L} P_{L}+\left(r_{S} Z_{S}+r_{L} Z_{L}\right) \chi\right)(1-\gamma)-g_{D_{S}}\left(1-e^{-\Lambda D_{S}}\right) Z_{S}-\left(c_{D_{S}}+\omega_{D_{S}} h^{-1}\right) D_{S}$

$\frac{\partial D_{L}}{\partial t}=(1-\lambda)\left[\left(g_{P_{S}}\left(1-e^{-\Lambda P_{S}}\right)+g_{P_{L^{2}}}\left(1-e^{-\Lambda P_{L}}\right)\right) Z_{S}+\left(g_{P_{L} 1}\left(1-e^{-\Lambda P_{L}}\right)+g_{Z_{S}}\left(1-e^{-\Lambda Z_{S}}\right)\right) Z_{L}\right]+\delta_{S} Z_{S}+\delta_{L} Z_{L}-$

$\left(c_{D_{L}}+\omega_{D L} h^{-1}\right) D_{L}-g_{D_{L} 2}\left(1-e^{-\Lambda D_{L}}\right) Z_{S}-g_{D_{L} 1}\left(1-e^{-\Lambda D_{L}}\right) Z_{L}$

\section{DON equations}

$\frac{\partial D O N}{\partial t}=\left(m_{S} P_{S}+m_{L} P_{L}+\left(r_{S} Z_{S}+r_{L} Z_{L}\right) \chi\right) \gamma+\left(c_{D_{S}} D_{S}+c_{D_{L}} D_{L}\right) \zeta-c_{D O N} D O N$

\section{Nutrients equations}

$\frac{\partial \mathrm{NO}_{3}}{\partial t}=-\mu_{S} P_{S} \frac{N_{S_{-} U P}}{N_{S_{-} U P}+A_{U P}}-\mu_{L} P_{L} \frac{N_{L_{-} U P}}{N_{L_{-} U P}+A_{U P}}+\varphi N H_{4}$

$\frac{\partial \mathrm{NH}_{4}}{\partial t}=-\mu_{S} P_{S} \frac{A_{u p}}{N_{S_{-} U P}+A_{U P}}-\mu_{L} P_{L} \frac{A_{u p}}{N_{L_{-} U P}+A_{U P}}+\left(r_{S} Z_{S}+r_{L} Z_{L}\right)(1-\chi)+c_{D O N} D O N+\left(c_{D_{S}} D_{S}+c_{D_{L}} D_{L}\right)(1-\zeta)-\varphi N H_{4}(\mathrm{~B} 9)$

$\frac{\partial \mathrm{Fe}}{\partial t}=-\left(\mu_{S} P_{S} R_{S}+\mu_{L} P_{L} R_{L}-s_{F e} D_{L} F e\right)+R_{S}\left[\left(r_{S} Z_{S}+r_{L} Z_{L}\right)(1-\chi)+c_{D O N} D O N+c_{D_{S}} D_{S}+c_{D_{L}} D_{L}(1-\zeta)\right]$

\section{Nitrogen uptake}

$N_{S_{-} U P}=\frac{\mathrm{NO}_{3}}{\mathrm{~K}_{S_{-} \mathrm{NO}_{3}+\mathrm{NO}_{3}}}\left(1-\frac{\mathrm{NH}_{4}}{\mathrm{~K}_{\mathrm{NH}_{4}}+\mathrm{NH}_{4}}\right)$

$N_{L_{-} U P}=\frac{\mathrm{NO}_{3}}{\mathrm{~K}_{L_{-} \mathrm{NO}_{3}+\mathrm{NO}_{3}}}\left(1-\frac{\mathrm{NH}_{4}}{\mathrm{~K}_{\mathrm{NH}_{4}}+\mathrm{NH}_{4}}\right)$ 
https://doi.org/10.5194/gmd-2020-431

Preprint. Discussion started: 4 March 2021

(c) Author(s) 2021. CC BY 4.0 License.

$A_{U P}=\frac{N H_{4}}{K_{N H_{4}}+N H_{4}}$

\section{Other equations}

Phytoplankton growth rate

$\mu_{S}=\mu_{S 0} e^{k_{T} T} f(I) \psi_{S}(N, F e)$

$\mu_{L}=\mu_{L 0} e^{k_{T} T} f(I) \psi_{L}(N, F e)$

\section{Nutrient limitation}

$\psi_{S}(N, F e)=\min \left(\frac{N_{3}+N H_{4}}{K_{S_{-} N}+N_{3}+N H_{4}}, \frac{\mathrm{Fe}}{K_{S_{-} \mathrm{Fe}}+\mathrm{Fe}}\right)$

$\psi_{L}(N, F e)=\min \left(\frac{N_{3}+N H_{4}}{K_{L_{-} N}+N O_{3}+N H_{4}}, \frac{\mathrm{Fe}}{K_{L_{-} \mathrm{Fe}}+\mathrm{Fe}}\right)$

\section{Light limitation}

$f(I)=1-e^{-\frac{\alpha I}{\eta P_{M A X}}}$

\section{Light attenuation}

$I(Z)=I_{0} \exp ^{-k_{A} Z}$

$k_{A}=k_{W}+k_{C} \mathrm{Chl}+k_{D}\left(D_{S}+D_{L}\right)$

\section{Detritus decomposition and DON remineralization}

$c_{D S}=c_{D S 0} e^{k_{B}(T-10)}$

$545 c_{D L}=c_{D L 0} e^{k_{B}(T-10)}$

$c_{D O N}=c_{D O N 0} e^{k_{B}(T-10)}$

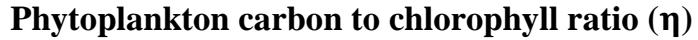

$\mathrm{Chl}=\left(\frac{P_{S}}{\eta_{S}}+\frac{P_{L}}{\eta_{L}}\right) R_{C: N}$

$$
\begin{aligned}
550 \quad \eta_{S} & =\eta_{S 0}-\left(\eta_{S 0}-\eta_{M I N}\right) \frac{\ln I_{0}-\operatorname{lnI} I}{4.605} \\
\eta_{L} & =\eta_{L 0}-\left(\eta_{L 0}-\eta_{M I N}\right) \frac{\ln I_{0}-\operatorname{lnI}}{4.605} \\
\eta_{S 0} & =\eta_{S_{-} M A X}-k_{P S} \mu_{S}^{*} \\
\eta_{L 0} & =\eta_{L_{-} M A X}-k_{P L} \mu_{L}^{*}
\end{aligned}
$$


https://doi.org/10.5194/gmd-2020-431

Preprint. Discussion started: 4 March 2021

(c) Author(s) 2021. CC BY 4.0 License.

(c) (i)

$\mu_{S}^{*}=\mu_{S 0} e^{k_{T} T} \min \left(\frac{N O_{3}}{K_{S_{-} N}+N O_{3}}, \frac{\mathrm{Fe}}{K_{S_{-}} \mathrm{Fe}+\mathrm{Fe}}\right)$

$555 \mu_{L}^{*}=\mu_{L 0} e^{k_{T} T} \min \left(\frac{N O_{3}}{K_{L_{-} N}+N O_{3}}, \frac{\mathrm{Fe}}{K_{L_{-} \mathrm{Fe}}+\mathrm{Fe}}\right)$ 


\section{Appendix B}

Model biogeochemical parameters

\begin{tabular}{|c|c|c|c|}
\hline Symbol & Parameter & Unit & Value \\
\hline$m_{\mathrm{S}}$ & Small phytoplankton mortality rate & $\mathrm{d}^{-1}$ & 0.15 \\
\hline$m_{\mathrm{L}}$ & Large phytoplankton mortality rate & $d^{-1}$ & 0.35 \\
\hline$r_{\mathrm{S}}$ & Small zooplankton excretion rate & $\mathrm{d}^{-1}$ & 0.53 \\
\hline$r_{\mathrm{L}}$ & Large zooplankton excretion rate & $\mathrm{d}^{-1}$ & 0.44 \\
\hline$\delta_{\mathrm{S}}$ & Small zootoplankton mortality rate & $d^{-1}$ & 0.12 \\
\hline$\delta_{\mathrm{L}}$ & Large zootoplankton mortality rate & $\mathrm{d}^{-1}$ & 0.12 \\
\hline$g_{\text {Ps }}$ & Maximum grazing rate for small phytoplanktion & $\mathrm{d}^{-1}$ & 2.6 \\
\hline$g_{\text {PL1 }}$ & Maximum grazing rate for large phytoplanktion & $d^{-1}$ & 1.2 \\
\hline$g_{\mathrm{Zs}}$ & Maximum grazing rate for small zootoplanktion & $\mathrm{d}^{-1}$ & 1.7 \\
\hline$g_{\mathrm{PL} 2}$ & Maximum grazing rate for large phytoplanktion & $\mathrm{d}^{-1}$ & 0.9 \\
\hline$g_{\text {Ds }}$ & Maximum grazing rate for small detritus & $\mathrm{d}^{-1}$ & 1.0 \\
\hline$g_{\text {DL1 }}$ & Maximum grazing rate for large detritus & $\mathrm{d}^{-1}$ & 3.0 \\
\hline$g_{\text {Dᄂ2 }}$ & Maximum grazing rate for large detritus & $\mathrm{d}^{-1}$ & 1.5 \\
\hline$\Lambda$ & Ivlev coefficient & $\left.(\mathrm{mmol} \mathrm{m})^{-3}\right)^{-1}$ & 0.5 \\
\hline$\lambda$ & Zootoplankton assimilation coefficient & $\%$ & 75 \\
\hline$\chi$ & Excretion coefficient & $\%$ & 55 \\
\hline$\gamma$ & Dissolution coefficient & $\%$ & 90 \\
\hline$\xi$ & Dissolution coefficient & $\%$ & 90 \\
\hline $\mathrm{R}_{\mathrm{C}: \mathrm{N}}$ & $\mathrm{C}: \mathrm{N}$ ratio & mol:mol & 6.625 \\
\hline $\mathrm{R}_{\mathrm{S}}$ & Fe: $\mathrm{N}$ ratio for small phytoplankton & $\mu \mathrm{mol}: \mathrm{mol}$ & 15 \\
\hline $\mathrm{R}_{\mathrm{L}}$ & $\mathrm{Fe}: \mathrm{N}$ ratio for large phytoplankton & $\mu \mathrm{mol}: \mathrm{mol}$ & 40 \\
\hline$\eta_{\mathrm{S} \_\mathrm{MIN}}$ & Minimum PhyC:Chl ratio in small phytoplanktion & $\mathrm{g}: \mathrm{g}$ & 30 \\
\hline$\eta_{\mathrm{L} \_\mathrm{MIN}}$ & Minimum PhyC:Chl ratio in large phytoplanktion & $\mathrm{g}: \mathrm{g}$ & 15 \\
\hline$\eta_{\text {S_MAX }}$ & Maximum PhyC:Chl ratio in small phytoplanktion & $\mathrm{g}: \mathrm{g}$ & 200 \\
\hline$\eta_{L_{-} \text {MAX }}$ & Maximum PhyC:Chl ratio in large phytoplanktion & g:g & 120 \\
\hline$k_{\mathrm{Ps}}$ & Photoacclimation coefficient for small phytoplanktion & $(g: g) d$ & 95 \\
\hline
\end{tabular}




\begin{tabular}{|c|c|c|c|}
\hline$k_{\mathrm{PL}}$ & Photoacclimation coefficient for large phytoplanktion & $(g: g) d$ & 70 \\
\hline$w_{\text {Ds }}$ & Sinking velocity for small detritus & $\mathrm{m} \mathrm{d}^{-1}$ & 1 \\
\hline$w_{\text {DL }}$ & Sinking velocity for large detritus & $\mathrm{m} \mathrm{d}^{-1}$ & 3.5 \\
\hline$\varphi$ & Nitrification rate (when $\mathrm{I}<5 \mu \mathrm{molEm}^{-2} \mathrm{~s}^{-1}$ ) & $\mathrm{d}^{-1}$ & 0.04 \\
\hline$s_{\mathrm{Fe}}$ & Iron scavenge coefficient & $\left.\mathrm{d}^{-1}(\mathrm{nmol} \mathrm{Fe} \mathrm{m})^{-3}\right)^{-1}$ & 0.00001 \\
\hline$\mu_{\mathrm{S} 0}$ & Maximum growth rate at $0^{\circ} \mathrm{C}$ for small phytoplankton & $\mathrm{d}^{-1}$ & 0.58 \\
\hline$\mu_{\mathrm{L} 0}$ & Maximum growth rate at $0^{\circ} \mathrm{C}$ for large phytoplankton & $\mathrm{d}^{-1}$ & 1.16 \\
\hline$k_{\mathrm{T}}$ & Temp. Dependent coefficient for $\mu$ & ${ }^{\circ} \mathrm{C}^{-1}$ & 0.06 \\
\hline $\mathrm{K}_{\mathrm{S} \_\mathrm{N}}$ & Half saturation constant for $\mathrm{N}$ limitation & $\mathrm{mmol} \mathrm{m}^{-3}$ & 0.3 \\
\hline $\mathrm{K}_{\mathrm{L} \_\mathrm{N}}$ & Half saturation constant for $\mathrm{N}$ limitation & $\mathrm{mmol} \mathrm{m}^{-3}$ & 0.9 \\
\hline $\mathrm{K}_{\mathrm{S} \_\mathrm{Fe}}$ & Half saturation constant for iron limitation & $\mathrm{mmol} \mathrm{m}^{-3}$ & 14 \\
\hline $\mathrm{K}_{\mathrm{L}_{-} \mathrm{Fe}}$ & Half saturation constant for iron limitation & $\mathrm{mmol} \mathrm{m}^{-3}$ & 150 \\
\hline $\mathrm{K}_{\mathrm{S} \_\mathrm{NO} 3}$ & Half saturation constant for nitrate uptake & $\mathrm{mmol} \mathrm{m}^{-3}$ & 0.3 \\
\hline $\mathrm{K}_{\mathrm{L} \_\mathrm{NO} 3}$ & Half saturation constant for nitrate uptake & $\mathrm{mmol} \mathrm{m}^{-3}$ & 0.9 \\
\hline $\mathrm{K}_{\mathrm{NH} 4}$ & Half saturation constant for ammonium uptake & $\mathrm{mmol} \mathrm{m} \mathrm{m}^{-3}$ & 0.05 \\
\hline$\alpha$ & Initial slope of the $\mathrm{P}-\mathrm{I}$ curve & $\mathrm{mg} \mathrm{C} \mathrm{mg} \mathrm{chl}{ }^{-1}\left(\mu m o l \mathrm{E} m^{-2} s^{-1}\right)^{-1}$ & 0.02 \\
\hline$P_{\text {MAX }}$ & Maximum carbon specific growth rate & $\mathrm{h}^{-1}$ & 0.036 \\
\hline$k_{\mathrm{W}}$ & Light attenuation constant for water & $\mathrm{m}^{-1}$ & 0.028 \\
\hline$k_{\mathrm{C}}$ & Light attenuation constant for chlorophyll & $\mathrm{m}^{-1}(\mathrm{mg} \mathrm{chl} \mathrm{m})^{-3)-1}$ & 0.058 \\
\hline$k_{\mathrm{D}}$ & Light attenuation constant for detritus & $\mathrm{m}^{-1}\left(\mathrm{mg} \operatorname{chl~m} \mathrm{m}^{-3)-1}\right.$ & 0.008 \\
\hline$c_{\text {Ds } 0}$ & Small detritus decomposition rate at $10^{\circ} \mathrm{C}$ & $\mathrm{d}^{-1}$ & 0.001 \\
\hline$c_{\text {DL0 }}$ & Large detritus decomposition rate at $10^{\circ} \mathrm{C}$ & $\mathrm{d}^{-1}$ & 0.008 \\
\hline \multirow[t]{3}{*}{$c_{\text {DON0 }}$} & DON remineraization rate $(0-100 \mathrm{~m})$ at $10^{\circ} \mathrm{C}$ & $\mathrm{d}^{-1}$ & 0.001 \\
\hline & $100-500 \mathrm{~m}$ at $10^{\circ} \mathrm{C}$ & $\mathrm{d}^{-1}$ & $0.0002-0.001$ \\
\hline & $>500 \mathrm{~m}$ at $10^{\circ} \mathrm{C}$ & $\mathrm{d}^{-1}$ & 0.0002 \\
\hline$k_{\mathrm{B}}$ & Temp. dependent coefficient for $\mathrm{c}$ & ${ }^{\circ} \mathrm{C}^{-1}$ & 0.02 \\
\hline
\end{tabular}

